\title{
FEDERALISMO FISCAL NA AMÉRICA LATINA: OS CAsos de MÉXICO, ARgentina E BRAsil
}

\author{
THIAGO GUERREIRO BASTOS ${ }^{\dagger}$ \\ EDUARDO MANUEL VAL ${ }^{\dagger \dagger}$
}

RESUMO: A forma federativa de estado representa a expressão política de um Estado dentro de seu território. Em razão da inexistência de modelos federativos universais e/ou globais, cada país assenta sua forma federativa a partir de práticas políticas passadas. A autonomia financeira ou poder político tributário, por certo, é um dos principais elementos em uma federação, pois será a partir dele que a descentralização política se efetivará. Por esse motivo, decidiu-se elaborar um trabalho focado no federalismo fiscal no âmbito da América Latina, em razão das proximidades socioeconômicas. Dessa forma, foram escolhidos três países: Estados Unidos Mexicanos, República Argentina e República Federativa do Brasil. Os três países, à sua maneira, rumaram para uma centralização fiscal, tendo, por motivos inerentes a cada um dos estados citados, variações em níveis de centralização. Contudo, o resultado final tende a ser próximo, qual seja, um federalismo fiscal ineficiente e que tende a sufocar as autonomias das unidades federadas.

\footnotetext{
† Mestre em Direito Constitucional pelo Programa de Pós-Graduação em Direito Constitucional da Universidade Federal Fluminense. Especialista em Direito Constitucional pela Universidade Cândido Mendes. Professor Substituto na Universidade Federal do Rio de Janeiro. Advogado. E-mail: thiagoguerreirobastos@gmail.com

† Doutor e Mestre em Direito Público pela Pontifícia Universidade Católica do Rio de Janeiro. Professor do Programa de Pós-Graduação Stricto Sensu em Direito Constitucional e Professor Adjunto de Direito Constitucional Internacional da Faculdade de Direito da Universidade Federal Fluminense. Professor do Programa de Pós-Graduação em Direito da Universidade Estácio de Sá. E-mail: eduardval11@hotmail.com
} 
Palavras-Chave: Federalismo Fiscal; América Latina; Méximo; Argentina; Brasil.

\begin{abstract}
The federalism is a unique expression of a political form adopted by the state. Because of that, it is possible to affirm that there is no universal or global model to be adopted by all the countries that aims the federal form. The tax power given to the subnational levels is the key to sustain a federal form because without it the political decentralization might not happen. Because of that, it was decided to develop a focused paper on fiscal federalism in America Latina context with three countries: Mexico, Argentina and Brazil. All three, in their own way, developed huge levels of fiscal centralization. In the end, the results tends to be very close in political terms and consequences to an inefficient fiscal federalism that tends to stifle the autonomy of the federated units.
\end{abstract}

KEYWORDS: Tax Federalism; Latin America; Mexico; Argentina; Brazil. 


\section{SUMÁRIO:}

I. INTRODUÇÃ

II. ESTADO FEDERAL .............................................................................935

1. Autonomia ............................................................................937

III. FEDERALISMO FISCAL NO CONTEXTO LATINO-AMERICANO.........939

1. Modelo Fiscal Mexicano ................................................940

2. Modelo Fiscal Argentino .......................................................946

3. Modelo Fiscal Brasileiro....................................................957

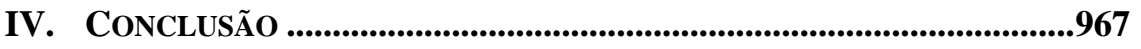

V. REFERENCIAS ...............................................................................968

\section{TABLE OF CONTENTS:}

I. INTRODUCTION ......................................................................935

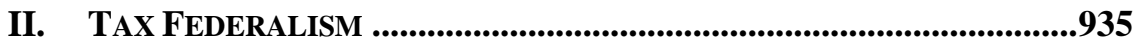

1. Autonomia ............................................................................937

III. TAX FEDERALISM IN LATIN AMERICAN CONTEXT .........................939

1. Mexican Tax Model ................................................................940

2. Argentine Tax Model............................................................946

3. Brazilian Tax Model .......................................................957

IV. CONCLUSION ................................................................................967

V. REFERENCES ...............................................................................968 


\section{INTRODUÇÃo}

O passado histórico de um país tem profunda relação com a forma de estado adotada e suas práticas políticas. De acordo com Augusto Zimmermann e Luís Roberto Barroso, os Estados podem ser classificados em simples (unitários) ou compostos (federativo / confederativo). ${ }^{1}$

O presente artigo, almeja, ainda que sem pretender esgotar o assunto, abordar um aspecto específico da forma composta de estado, federalismo fiscal. Tendo em vista o desafio de se fazer um trabalho com aporte de direito comparado, buscou-se, sobretudo, analisar os modelos fiscais argentino e mexicano a partir de doutrina tida como referência nestes países. Compreender a evolução do federalismo fiscal no contexto latinoamericano significa conhecer os problemas atrelados ao poder político tributário em países cuja evolução histórica é bastante semelhante a nossa. Dessa forma, abre-se espaço para novas perspectivas sobre o assunto, sendo este o principal objetivo deste sucinto ensaio fiscal no âmbito latino-americano.

Por fim, cabe ressaltar que atualmente há vinte e cinco nações sob a forma federal. Isto equivale, segundo o Forum of Federation, a cerca de $40 \%$ da população global ${ }^{2}$. Logo, há uma pluralidade de modelos federativos com inúmeros arranjos peculiares. O motivo pelo qual se escolheu o modelo argentino e mexicano, conforme dito anteriormente, decorre das semelhanças históricas com o Brasil.

\section{ESTADO FEDERAL}

A forma federal é fruto de um acordo político no plano interno que se materializa por meio de uma constituição. O principal objetivo desta articulação é assegurar a pluralidade de centros decisórios no mesmo espaço geográfico. De acordo com a teoria dos Estados-membros não soberanos ${ }^{3}$, os entes subnacionais se expressam politicamente dentro de

\footnotetext{
${ }^{1}$ Cf. ZIMMERMANN, Augusto. Teoria Geral do Federalismo Democrático. Rio de Janeiro, RJ: Lumen Juris, 1999; e BARROSO, Luís Roberto. Direito Constitucional Brasileiro: o Problema da Federação. Rio de Janeiro, RJ: Forense, 1982.

${ }^{2}$ Forum of Federations - The Global Network on Federalism and Devolved Governance. Disponível em: <http://www.forumfed.org/countries/>. Acessado em: 29 de setembro de 2016.

${ }^{3}$ De acordo com Luís Roberto Barro e Sérgio Ferrari, o debate teórico acerca da natureza jurídico do vínculo existente entre os Estados-membros e a União pode ser
} 
suas circunscrições territoriais graças a autonomia. Esta, por sua vez, se decanta em vertente política, administrativa e tributária, dentro dos limites constitucionalmente previstos.

Conforme dito anteriormente, a constituição federal materializa o pacto federativo, logo, presume-se a inexistência de outro documento político com idêntico teor em razão das peculiaridades de cada país. Esta premissa impossibilita a existência de um "federalismo universal" ou de modelo a ser seguido. A fim de reforçar este posicionamento, merece destaque a Medida Cautelar em Ação Direta de Inconstitucionalidade $\mathbf{n}^{\mathbf{o}}$ $216^{4}$ cujo relator foi Ministro Célio Borja. Ao longo do acórdão, o Ministro Paulo Brossard cita João Mangabeira Unger no intuito de estabelecer a inexistência de um conceito ou padrão federativo global.

JOAO MANGABEIRA já afirmou que não há padrão federativo, um padrão mundial de federação; havia federações, a federação americana era diferente da federação canadense; a federação brasileira era diferente da argentina e assim por diante. A federação americana não pode ser uma espécie de metro do irídio conservado em Paris, como padrão da décima milionésima parte do quarto do meridiano terrestre. Textualmente: (...) o regime federativo não se vasa num molde permanente. (...) A federação é uma forma de Estado; um sistema de composição de forças, interesses e objetivos, variável no tempo e espaço, e inerente e peculiar a cada povo.

Ronald Watts também defende a inexistência de uma forma federativa aplicável a todos os lugares de forma indistinta, pois os arranjos institucionais que promovem a distribuição de poder político entre as unidades variam de acordo com as peculiaridades locais. ${ }^{5}$ Cristiano Franco Martins, por seu turno, salienta que o grau de descentralização política vertical varia entre os estados federais, podendo ser de primeiro ou segundo grau, ou seja, bidimensional ou tridimensional, respectivamente. Dos inúmeros traços atrelados à pulverização do poder político no espaço territorial, por questões de afinidade com o tema do artigo, destacar-se-á, ainda que sucintamente, a autonomia.

compreendido através de cinco teorias distintas: Dupla Soberania, Nulificação, Estado Federal Único, Três Entidades Estatais e Estados-membros Não Soberanos.

${ }_{4}^{4}$ STF, ADI 216-MC, Min. Rel. Celio Borja, Tribunal Pleno. Julgamento em: 23.05.1990.

${ }^{5}$ WATTS, Ronald. Comparing Federal Systems in the 1990s, Kingston, Ont: Queen's University, 1996. 


\section{Autonomia}

É aquilo que o ente subnacional retém da sua antiga soberania ${ }^{6}$ ou adquire se oriundo de um modelo unitário. Compete à constituição distribuir o poder político de modo a trazer equilíbrio institucional entre os entes federados ${ }^{7}$. De acordo Luís Roberto Barroso, a repartição deste poder no texto constitucional "exclui a relação de subordinação hierárquica dos órgãos locais aos do Poder Central". Para Cristiano Franco Martins, autonomia é um estágio intermediário entre a soberania existente em uma confederação e a submissão em um estado unitário que se expressa pela "capacidade [do ente] de tomar decisões e de elaborar leis próprias, concretizando-as pelas suas próprias forças".

Desse modo, a liberdade política dos entes não decorre de ato volitivo da União, mas de um acordo político expressado na constituição a fim de trazer segurança institucional. Em relação à autonomia, é preciso compreendê-la como um conceito amplo que se desdobra em subitens de conteúdo autônomo. Para que haja federalismo é necessário haver a vertente política, administrativa e tributária. É a junção desses elementos que diferencia um Estado Unitário do Federal. As três vertentes podem ser melhor compreendidas da seguinte forma: Poder Político Tributário, Poder Político Administrativo e Poder Político Lato Sensu ${ }^{8}$.

Poder Político Tributário ${ }^{9}$ (Autonomia Financeira) é a capacidade de o ente subnacional gerar receitas próprias a fim de executar suas

${ }^{6}$ Importante salientar que para Dalmo de Abreu Dallari, a decisão política de aderir à federação é o último ato soberano realizado pelo antigo Estado-componente. DALLARI, Dalmo de Abreu. O Estado Federal. São Paulo, SP: Ática, 1986.

${ }^{7}$ De acordo com Dalmo de Abreu Dallari: “O problema das competências pode ser considerado o ponto central da organização federativa. É indispensável, antes de tudo, que a distribuição das competências entre a União e os Estados seja feita na própria Constituição, para não haver o risco de que a perda ou a redução excessiva das autonomias rompa o equilíbrio federativo ou mesmo anule a federação, criando um Estado que, na realidade, seja unitário pela centralização do poder. É importante acentuar que no Estado Federal o que se tem é uma descentralização política e não apenas administrativa, isto é, existem múltiplos centros de decisão, cada um tendo exclusividade em relação a determinados assuntos, o que é muito mais do que a simples descentralização da execução.". DALLARI, Dalmo de Abreu. O Estado Federal. São Paulo, SP: Ática, 1986.

${ }^{8}$ Importante informar que a classificação apresentada toma como base os conceitos tradicionais existentes na doutrina.

${ }^{9}$ De acordo com José Mauricio Conti, “A competência tributária é importante instrumento do federalismo, uma vez que confere ao ente federado uma fonte 
obrigações constitucionais sem depender financeiramente do Governo Central $^{10}$. Por este motivo, o sistema fiscal deve possuir mecanismos de transferências verticais que possibilitem o desenvolvimento de regiões economicamente atrasadas para assegurar seu pleno desenvolvimento. A questão fiscal é um dos principais pilares da autonomia, pois sem recursos próprios e suficientes os demais desdobramentos autônomos ficam prejudicados. Frisa-se mais uma vez: para que haja poder político financeiro é preciso que as receitas orçamentárias estaduais sejam suficientes para possibilitar a administração e funcionamento da máquina estadual ${ }^{11}$.

Poder Político Administrativo (Autoadministração) é a capacidade política para gerir a própria administração (bens e serviços) sem intervenção federal. No federalismo cooperativo há também a inclusão de competências administrativas de caráter comum, ocorrendo, assim,

independente de recursos, indispensável para garantir sua autonomia financeira. Mas não assegura a suficiência de recursos, outro pilar no qual se sustenta a autonomia financeira. Isso porque a partilha de competência tributárias é essencialmente vinculada a critérios de eficiência alocativa, em que se atribui a competência para tributar ao ente da Federação capaz de fazê-lo com maior eficiência. (...) A atribuição de competências tributárias, isoladamente, é instrumento incapaz de assegurar a suficiência de recursos aos entes federados. Complementa-se com o que pode ser considerado o principal instrumento de federalismo fiscal: a repartição do produto da arrecadação e o sistema de transferências intergovernamentais.". CONTI, José Maurício. Considerações sobre o Federalismo Fiscal Brasileiro em uma Perspectiva Comparada. In: José Mauricio Conti; Fernando Facury Scaff; Carlos Eduardo Faraco Braga (Coords.). Federalismo Fiscal: Questões Contemporâneas. Florianópolis, SC: Conceito, 2010, p. 24.

10 "Desde una perspectiva apremiante, podría afirmarse que el verdadero núcleo del federalismo -o de cualquier tipo de relaciones entre distintos niveles de gobierno- está sin duda en la distribución del dinero. Todo lo demás puede ser muy importante, pero no es lo fundamental." MERINO, Mauricio. El Federalismo e Los Dineros. Nexos: Sociedad, Periodismo y Literatura, No. 210, 1995. Disponível em: $<$ http://www.nexos.com.mx/?p=7442>. Acesso em: 21 de janeiro de 2016.

${ }^{11}$ Interessante destacar a Proposta de Emenda à Constituição nº 82/2007 que prevê o fortalecimento da Advocacia Pública, pois quanto mais fortalecida estiver a carreira, maior será sua atuação para obtenção de receitas dentro da circunscrição de cada ente federado. Como consequência, ocorrerá aumento na arrecadação fiscal dos entes subnacionais. Ressalta-se, ainda, que é imprescindível que os entes mantenham suas alíquotas tributárias sempre atualizadas a fim de fortalecer seu caixa. 
uma sobreposição na qual todos os entes atuam de forma coordenada em determinado tema por força constitucional.

Poder Político Lato Sensu é constituído de três elementos, sendo eles: Elemento organizativo (auto-organização); Elemento de governo (autogoverno); Elemento legislativo (autolegislação).

\section{FEDERALISMO FISCAL NO CONTEXTO LATINO-AMERICANO}

A forma federal é utilizada por diversos países no mundo. No continente americano, por exemplo, há diversos modelos e experiências únicas. Algumas foram frutíferas, outras nem tanto. Enquanto Estados Unidos, Canadá, México, Brasil, Venezuela e Argentina implementaram a forma federativa em definitivo, a despeito de turbulência políticas no passado, outros países como Chile e Colômbia que inicialmente eram federativos rumaram para a forma unitária. Na América Latina há quatro países que adotam a forma federal: México, Argentina, Brasil e Venezuela. No entanto, a pesquisa não incluiu este último por causa do complexo sistema político venezuelano. Além disso, excesso de países prejudicaria a elaboração do trabalho.

Por fim, salienta-se que a influência do modelo estadunidense é inevitável, mas reforça-se a inexistência de um federalismo universal pautado a partir da experiência americana. Admitir a influência não pode ser entendido como sinônimo de "cópia" do federalismo ianque ${ }^{12}$.

${ }^{12} \mathrm{O}$ passado colonial da América Hispânica e Portuguesa foi bastante similar no tocante à centralização do poder político. No entanto, no dia-a-dia colonial, as grandes distâncias e o isolamento dos povoados geraram o gérmen federativo por meio dos Cabildos no Vice-Reinado de Nova Espanha (desdobramento que gerou o atual território mexicano) e Vice-Reinado do Rio da Prata (fragmentação que originou a Argentina). No Brasil, tal mecanismo ocorreu a partir da Câmaras Coloniais. A formação nacional do México e Argentina é centrípeta porque com a efetivação da independência (México: de 1810 a 1821; Argentina: 1810 a 1816) cada unidade territorial ao redor dos Cabildos se declarou independente, vindo, posteriormente, a se unir em laço federativo. O Brasil, por outro lado, sempre manteve a forma unitária. A independência em 1822 sob a forma monárquica atingiu seu principal objetivo, qual seja, manter a unidade territorial, algo que México e Argentina não conseguiram ao longo de sua formação nacional. 


\section{Modelo Fiscal Mexicano}

Curiosamente, assim como o Brasil, primeira experiência mexicana como Estado soberano foi sob a forma monárquica, isto é, unitária. No entanto, por ter sido extremamente malsucedida, foi substituída pela forma republicana e adotou a forma federativa. A formação mexicana passou por problemas similares, mas não idênticos aos enfrentados pelos Estados Unidos da América durante a transição de Colônia para Estadonação. Há duzentos anos o México tenta atingir seu equilíbrio federativo. ${ }^{13}$

O sentimento federativo mexicano tem origem nos antigos Cabildos (estruturas responsáveis por fomentar a descentralização local ${ }^{14}$ ), motivo pelo qual os Municípios nos países latinos tendem a ser mencionados em seus textos constitucionais a fim de assegurar-lhes autonomia. De acordo com Tulio Halperin Donghi, os Cabildos eram fortalezas da elite:

Sin duda encontramos cámaras municipales semejantes en su estructura y su origen a los cabildos, como éstos fortalezas de oligarquías municipales que se renuevan por cooptación, por herencia o por compra de cargos. ${ }^{15}$

Portanto, com a efetivação da independência em 1821, e consequente implementação da forma monárquica, inúmeras Províncias se declararam independentes a fim de rechaçar a centralização política que se pretendia efetivar. A tensão política interna somente foi apaziguada por meio da Acta Constitutiva, documento que firmou o compromisso constituinte pela República e Federação. A forma federal mexicana teve alguns condicionantes: passado histórico colonial que incentivou a descentralização, veto a troca de uma subordinação de Madri pela Cidade do México e, tentativa de arrefecimento das dissensões internas para

${ }^{13}$ Cf. CAMACHO, César. Propuesta de un Nuevo Diseño Competencial para el Federalismo Mexicano. In: José María Serna de la Garza (Coord.). Federalismo y Regionalismo: Memoria del VII Congreso Iberoamericano de Derecho Constitucional. Ciudad de Mexico: Universidad Nacional Autónoma de Mexico, 2002. ${ }^{14}$ Os termos Cabildos (Argentina), Ayuntamientos (México) e Câmaras Coloniais (Brasil) representam em cada Estado analisado o centro político municipal.

${ }^{15}$ DONGHI, Tulio Halperín. Historia Contemporanea de America Latina. Madrid: Alianza Editorial, 2005. 
manter a integridade do território ${ }^{16}$. Tentou-se manter o território intacto e compatibilizá-lo com ânsia autônoma das Províncias.

Los hechos señalados son la base del sistema federal mexicano, que fue una necesidad y realmente sirvió para unir lo que se estaba desuniendo. Es decir, en México, el régimen federal no fue una solución de gabinete, teórica, irreal, sino que fue el anhelo de las provincias, por el que lucharon y triunfaron. ${ }^{17}$

Esse é o cenário político da primeira experiência federativa mexicana sob a égide da Constituição de 1824. Contudo, a forma federal adotada surgiu enfraquecida, pois o governo federal era fraco e debilitado frente às Províncias que detinham força e pujança econômica. Segundo Marcelo Carmagnani, o Estado federal mexicano de 1824 era, na verdade, uma Confederação, pois o texto assegurou a soberania dos entes ${ }^{18}$.

A instabilidade pós 1824 culminou na dissolução do Congresso em 1833 e adoção da forma unitária a fim de salvaguardar a unidade territorial (principalmente a Província do Texas). Argumentou-se que o antigo Governo Central era incapaz de promover a segurança e a saúde das finanças públicas ${ }^{19}$. A forma federal é resgatada com a Constituição de 1857 e mantida com a Revolução Mexicana de 1911 que deu origem ao atual documento político de 1917.

O sucinto recorte histórico buscou demonstrar que a experiência federativa no México foi turbulenta, pois até sua efetivação formal houve transições para forma unitária. Como pano de fundo, é possível enxergar as mudanças sofridas no federalismo fiscal, elemento essencial em uma federação por materializar o Poder Político Tributário. A preexistência dos Estados-membros em relação à federação influenciou a discussão e o

${ }^{16}$ CARPIZO, Jorge. Sistema Federal Mexicano. In: Pedro Pablo Camargo, et. al.

(Coords.). Los Sistemas Federales del Continente Americano. Ciudad de Mexico: Fondo de Cultura Económica, 1972, p. 463-548.

${ }_{17}$ CARPIZO, Jorge. Sistema Federal Mexicano. In: Pedro Pablo Camargo, et. al.

(Coords.). Los Sistemas Federales del Continente Americano. Ciudad de Mexico: Fondo de Cultura Económica, 1972, p. 463-548.

${ }^{18}$ CARMAGNANI, Marcello (Coord.). Federalismos Latinoamericanos: México,

Brasil, Argentina. Ciudad de Mexico: Fondo de Cultura Económica, 1993.

${ }^{19}$ Curioso observar os caminhos políticos opostos adotados pelo México e Estados Unidos, pois enquanto a ineficiência da União estadunidense gerou novo texto político mais centralizado em face dos antigos artigos confederados, no México a centralização foi tão incisiva que rumou para forma unitária de estado. Ressalta-se, inclusive, que nesse período unitário ocorreram perdas territoriais significativas. 
desenho fiscal, pois fez com que os entes subnacionais mantivessem grande parcela deste poder político. A Constituição de 1857 cedeu ao Governo Central a competência exclusiva sobre importação, exportação, rendas de cunhagem e selos. No entanto, eliminou os impostos aduaneiros estaduais sob a justificativa de incentivo à circulação de bens no mercado interno ${ }^{20}$. A discussão da saúde fiscal retornou em $1880 \mathrm{em}$ razão da criação de impostos federais que geraram perda de poder fiscal por parte dos Estados:

(...) para hacer frente a la crisis fiscal, introdujo nuevos impuestos que afectaban las manufacturas nacionales y extranjeras. Conociendo bien la resistencia que estos nuevos impuestos federales habrían generado por el hecho de que podían ser declarados inconstitucionales en cuanto afectaban los poderes residuales que pertenecían a los estados, el gobierno federal trató de implementarlos gradualmente entre 1880 y 1884 sin que por ello pasaran inadvertidos. Los nuevos impuestos federales desataron una fuerte oposición tanto a nivel de los intereses económicos afectados como a nivel de los intereses de los estados, que veían en los nuevos impuestos un atentado a su autonomía financiera. ${ }^{21}$

A questão tributária não foi alterada pela Constituição de 1917, mantendo-se a União como titular de poucos tributos de forma taxativa (Imposto de Importação, Exportação e Imposto de Selo). A doutrina e a jurisprudência, no entanto, passaram a vislumbrar o caráter concorrente de todos os entes para os tributos não entregues de forma expressa à União. Nesse momento, houve aproximação com a postura fiscal dos Estados Unidos. Entretanto, este desenho fiscal não foi cópia da solução estadunidense, pois o tema já era debatido desde a Constituição de 1857:

La adopción de dicho régimen de "concurrencia" no obedeció a la casualidad, sino que respondió a un propósito deliberado. En efecto, al debatir sobre la fórmula de distribución de competencias en materia tributaria, el Constituyente de 1857 tuvo a la vista dos opciones: la primera de ellas consistió

${ }^{20}$ Discutia-se mais sobre o impacto nas finanças estaduais do que os possíveis benefícios gerados pelo desenvolvimento da livre circulação, pois se temia a dependência fiscal em face da União. CARMAGNANI, Marcello (Coord.).

Federalismos Latinoamericanos: México, Brasil, Argentina. Ciudad de Mexico: Fondo de Cultura Económica, 1993.

${ }^{21}$ CARMAGNANI, Marcello (Coord.). Federalismos Latinoamericanos: México, Brasil, Argentina. Ciudad de Mexico: Fondo de Cultura Económica, 1993. 
en establecer con precisión cuáles impuestos corresponderían a la Federación y cuáles a las entidades federativas; la segunda descansó en la idea de no establecer una delimitación de campos impositivos, sino en dejar abierta la posibilidad de que ambos niveles de gobierno pudieran establecer los impuestos que fueran necesarios para cubrir sus respectivos presupuestos de gastos. $^{22}$

A discussão fiscal na constituinte de 1857 se pautou em dois caminhos: 1) Delimitação rígida em matéria tributária, mas que poderia gerar o enrijecimento excessivo do modelo e dificultar a atuação da União; 2) Competência concorrente para atender as plenas necessidades, mas que poderia desencadear excessivo peso tributário e posterior sufocamento da economia. Optou-se, pelo primeiro modelo. Contudo, a realidade impôs uma nova releitura das competências via Tribunal Constitucional Mexicano.

A conversão do sistema tributário rígido para um flexível gerou nas primeiras décadas do atual texto político uma total anarquia fiscal ${ }^{23}$ cuja primeira tentativa de solução ocorreu em 1925. Neste ano, o Ministério da Fazenda a pedido do presidente Plutarco Elías Calles convocou uma reunião com todos os Estados-membros com o objetivo de estudar a divisão das competências tributárias, ficando conhecida como "Primeira Convenção Nacional Fiscal"24. O intenso debate político culminou na proposta de total discriminação do Poder Político Tributário de cada

22 SERNA DE LA GARZA, José María. Aspectos Constitucionales del Federalismo Fiscal Mexicano. In: Gabriela Ríos Granados (Coord.). Reforma Hacendaria en la Agenda de la Reforma del Estado. Ciudad de Mexico: Universidad Nacional Autónoma de Mexico, 2009.

${ }^{23}$ A anarquia fiscal (bitributação) assolou a economia mexicana, sendo definida por José María Serna de la Garza como: “(...) generalizó la doble y hasta múltiple imposición, provocando serios daños a la actividad económica nacional al incidir de manera acumulada y superpuesta sobre las mismas bases. Bajo este esquema, los contribuyentes se veían obligados a pagar múltiples impuestos, conforme a una multiplicidad de normas, aplicadas por autoridades diversas, a través de procedimientos de recaudación distintos". SERNA DE LA GARZA, José María. Aspectos Constitucionales del Federalismo Fiscal Mexicano. In: Gabriela Ríos Granados (Coord.). Reforma Hacendaria en la Agenda de la Reforma del Estado. Ciudad de Mexico: Universidad Nacional Autónoma de Mexico, 2009, p. 10. ${ }^{24}$ CARPIZO, Jorge. Sistema Federal Mexicano. In: Pedro Pablo Camargo, et. al. (Coords.). Los Sistemas Federales del Continente Americano. Ciudad de Mexico: Fondo de Cultura Económica, 1972, p. 463-548. 
unidade federativa. Além disso, foi proposto mecanismos de transferências verticais a fim equilibrar o sistema fiscal. No entanto, os trabalhos da convenção enviados ao Congresso para iniciar uma reforma tributária foram rejeitados.

A crise econômica de 1929 propiciou a federalização de tributos em razão do apelo macroeconômico da União para superação da crise. Nesse contexto, foi feita a Segunda Convenção Nacional Fiscal que almejava delimitar a atuação fiscal de cada unidade. No entanto, o efeito concreto do encontro foi a transferência para o governo federal da competência sobre energia elétrica sob a condição de repartir com Estados e Municípios a receita arrecadada. De acordo com José María Serna de la Garza, esta reforma marca o início da prática de centralização tributária com transferências de percentuais aos demais entes.

A superação do gargalo fiscal mexicano somente ocorreu após Terceira Convenção Nacional Fiscal de $1947^{25}$. Entretanto, a solução pactuada favoreceu imensamente a União, pois gerou a concentração tributária em seu favor, cabendo-lhe entregar percentuais do montante arrecadado aos entes subnacionais. Esse momento político foi a origem do atual Sistema Nacional de Coordenação Fiscal (SNCF). É importante ressaltar que o SNCF tem assento infraconstitucional, não sendo, portanto, imposto aos demais entes políticos. A adesão é feita por meio de convênios entre União e Estados-membros onde o ente infranacional concorda em não exercer seu poder político tributário em troca de transferências do montante arrecadado ${ }^{26}$. Sobre o SNCF:

En el ámbito fiscal, destacan las reformas de 1979 y 1980, años en los cuales se crea el Impuesto al Valor Agregado (IVA), que sustituye al Impuesto sobre Ingresos Mercantiles (ISIM) y se crea el Sistema Nacional de Coordinación Fiscal (SNCF). (...) El objetivo del SNCF era transformar el Sistema de Participaciones e la colaboración administrativa que prestaban las Haciendas

${ }^{25}$ O Sistema Nacional de Coordenação Fiscal é bastante criticado, pois além de restringir excessivamente o Poder Político Tributário dos Estados-membros, não foi constitucionalizado. Adrían Miranda Camarena sustenta que sua ausência fortalece o Governo Central ao lhe dar imenso poder discricionário. A tese também é defendida por Yemile Mizrahi.

${ }^{26}$ O domínio político exercido pelo Partido Revolucionário Institucional (PRI) foi essencial para a centralização fiscal, pois o partido era amplamente hegemônico em todos os níveis de governo. 
estatales a la federal y evitar la doble (y hasta triple), tributación que existía en aquél entonces. ${ }^{27}$

A solução para superar a bitributação no México perpassou pela centralização tributária ${ }^{28}$. O sufocamento fiscal sofrido afeta diretamente o Poder Político Tributário que é um dos principais pilares da forma federal $^{29}$. De acordo com Adrían Joaquín Miranda Camarena:

No obstante, reitero, no es la mejor solución seguir transfiriendo recursos por parte de la Federación a los estados y en su caso municipios, convirtiéndolos en simples órganos administrativos dependientes en un muy alto porcentaje

${ }^{27}$ RUIZ, Javier Obregón. Fortalecimiento del Federalismo Fiscal en México.

Documento de Trabajo (Fundación Rafael Preciado Hernández A.C.), No. 482, 2013.

Disponível em:

$<$ https://www.academia.edu/9435848/DOCUMENTOS DE TRABAJO Fortalecimiento del Federalismo Fiscal en M\%C3\%A9xico 482>. Acesso em: 31 de janeiro de 2017.

${ }^{28}$ A doutrina mexicana (José María Serna de la Garza, José Carbonell, Adrían Joaquín Miranda Camarena, Jorge Carpizo, entre outros) critica com severidade os níveis de centralização atingidos. Nesse sentido, Luis Manuel Acha afirma que o fortalecimento das fazendas estaduais é o principal objetivo do "novo federalismo" mexicano que se almeja chegar, pois é inadmissível que "Los ingresos por fuentes tributarias propias de las entidades federativas ascienden apenas al 10\%; el restante $90 \%$ les viene de transferencias federales. Eso explica la debilidad de las haciendas estatales y municipales, y como contrapartida, el nivel de dependencia de éstas con el gobierno federal". ACHA, Luis Manuel Pérez de. Federalismo Hacendario (Propuestas Constitucional y Legal 2007). In: Gabriela Ríos Granados (Coord.). Reforma Hacendaria en la Agenda de la Reforma del Estado. Ciudad de Mexico: Universidad Nacional Autónoma de Mexico, 2009.

${ }^{29}$ Destaca-se que a Federação pode reter percentuais para quitar dívidas públicas com a União. "Por último, cabe mencionar que las participaciones que corresponden a las entidades y municipios sí pueden ser retenidas y afectadas por la Federación, para el pago de obligaciones financieras contraídas a favor de la Federación, de las instituciones de crédito que operen en el país, así como de las personas físicas o morales de nacionalidad mexicana. Además, la Ley de Coordinación Fiscal no contempla ningún tipo de garantía de la cual puedan disponer los estados en caso de que el Ejecutivo federal, a través de la Secretaría de Hacienda y Crédito Público, determine la retención y su afectación al pago de las deudas contraídas". SERNA DE LA GARZA, José María. Las Convenciones Nacionales Fiscales y el Federalismo Fiscal en México. Ciudad de Mexico: Universidad Nacional Autónoma de Mexico, 2004, p. 30.

2 JOURNAL OF INSTITUTIONAL STUDIES 2 (2016) 
de la Federación, lo que los vuelve ineficientes y rompe con la estructura federal. ${ }^{30}$

É importante destacar que as transferências condicionadas são mais significativas do que as incondicionadas ${ }^{31}$ no contexto mexicano. Esta constatação, aponta para uma homogeneização forçada da diversidade, substituindo o interesse local/regional pelo federal. Além disso, cabe destacar a ausência de paridade entre capacidade fiscal arrecadatória com poder de determinar gastos, isto é, o SNCF impõe uma baixa aptidão de gerar ingressos fiscais próprios, mas gera uma grande capacidade de conferir gastos públicos por parte dos governos subnacionais. Isto, por si só, gera um cenário fiscal confuso, inadequado e incompatível com a forma federal. ${ }^{32}$ De forma semelhante, Javier Obregón Ruiz critica com severidade o fato do federalismo fiscal mexicano não incentivar que as unidades sejam fiscalmente eficientes.

\section{Modelo Fiscal Argentino}

O surgimento da Argentina como Estado está ligado às reformas Bourbônicas de 1776, que promoveram o desmembramento de parte do Vice-Reinado do Peru para a criação do Vice-Reinado do Rio da Prata. Tal medida se pautou em dois critérios: 1) econômico, pois o porto de Buenos

${ }^{30}$ MIRANDA CAMARENA, Adrián Joaquín. Análisis del Federalismo Hacendario Mexicano. 2010. 268 f. Tese (Doutorado em Direito Constitucional), Universidad Carlos III de Madrid, Madrid, 2010.

${ }^{31}$ José Maria Serna de la Garza apontou, exemplificativamente, que a Província de Querétaro (ente de bom nível de desenvolvimento econômico) tem o seguinte cenário fiscal: 1) ingressos próprios em $\$ 377,841,000.00 ; 2)$ participação na arrecadação federal em $\$ 3,55^{\prime} 373,00.00$ e, 3) aportações em $\$ 4,498,409,000.00$. A soma dos ingressos incondicionados é inferior ao montante transferido a título de "aportaciones". Nesse mesmo sentido: “(...) los gobiernos estatales y municipales están bastante desincentivados para hacerse cargo de la recaudación de impuestos y financiar sus presupuestos, ya que viven literalmente de las transferencias que realiza la federacións. Y sin embargo, pareciera que los recursos proveniente del centro, tampoco son suficientes pues el común denominador de las Entidades Federativas es el alto endeudamiento, lo cual pondría en riesgo la estabilidad financiera de la federacións". 32 MIRANDA CAMARENA, Adrián Joaquín. Análisis del Federalismo Hacendario Mexicano. 2010. 268 f. Tese (Doutorado em Direito Constitucional), Universidad Carlos III de Madrid, Madrid, 2010, p. 213-216. 
Aires era estratégico para escoamento da prata e, 2) segurança, pois a divisão facilitaria a administração do Cone Sul que vinha sofrendo com avanço dos portugueses. Nesse contexto, permitiu-se o amplo desenvolvimento administrativo e econômico da cidade de Buenos Aires e de sua província, colocando-as em um patamar de superioridade em relação aos demais núcleos constituintes do Vice-Reino ${ }^{33}$.

A região do Prata era composta pelos atuais territórios da Argentina, Bolívia, e Uruguai, possuindo a mesma estrutura administrativa do resto do império hispânico. Portanto, os Cabildos promoveram a descentralização política local que será o gérmen do sentimento federativo argentino. De acordo com Juan Bautista Alberdi, não há dúvidas da influência da estrutura colonial no desenvolvimento da vida política argentina:

La descentralización política y administrativa de la República reconoce dos orígenes: uno mediato y anterior a la revolución; otro inmediato y dependiente de este cambio. El mediato origen es el antiguo régimen municipal español, que en Europa como en América era excepcional y sin ejemplo por la extensión que daba al poder de los Cabildos o representaciones elegidas por los pueblos. Esa institución ha sido la primera forma, el primer grado de existencia del poder representativo provincial entre nosotros, como la ha sido en España misma; (...) Con doble motivo el localismo conservó aquí mayor latitud que la conocida en las provincias de España con el nombre de fueros y privilegios. (...) La unidad del gobierno de los virreinatos no excluía la existencia de gobiernos de provincia dotados de un poder extenso y muchas veces peculiar. (...) Vemos, pues, que el gobierno local o provincial es uno de nuestro antecedentes administrativos, que remonta y se liga a la historia de España y de su gobierno colonial en América: por lo cual constituye una base histórica que debe servir de punto de partida en la organización constitucional del país. ${ }^{34}$

A força política, econômica e administrativa alcançada por Buenos Aires foi fruto do seu status de capital do Vice-Reino e, evidentemente, de sua posição estratégica na foz do Rio da Prata. As tensões que se desenrolaram ao longo do processo de independência (1816) têm íntima relação com sua trajetória política no território argentino, pois sempre

${ }^{33}$ A criação desta região no Rio da Prata alçou Buenos Aires à condição de centro político altamente concentrado. A predominância da capital do Vice-Reinado gerou tensões que postergaram a formação do estado nacional argentino.

${ }^{34}$ ALBERDI, Juan Bautista. Bases y puntos de partida para la Organización Política de la República Argentina. Buenos Aires: La Cultura Argentina, 1915.

2 JOURNAL OF INSTITUTIONAL STUDIES 2 (2016) 
tentou eclipsar as demais unidades sobre seu domínio. De acordo com José Carlos Chiaramonte, as investidas da antiga capital e a resistências das demais unidades gerou duas posições políticas: 1) todas as Províncias são dotadas de soberania, tornando Buenos Aires apenas mais uma dentre todas que compõe a região do Rio da Prata e, 2) defende a proeminência da antiga capital em razão de seu passado histórico como sede do Vice-reino, por sua estrutura político-administrativa e por sua posição geoestratégica na foz do Rio da Prata ${ }^{35}$.

O período de 1816 a 1853 foi marcado por ampla polarização dessas duas forças políticas (Província de Buenos Aires versus Províncias do interior). A primeira tentativa de elaborar uma constituição para a região ocorreu em 1819, fruto do Congreso de Tucumán, mas seu conteúdo conservador, centralista e pró-monárquico não foi aceito por inúmeras unidades. A tensão entre unitaristas e federalistas teve como clímax a Batalla de Cepada em 1820. Uma nova constituinte foi convocada cujos trabalhos deram origem ao texto de 1826, mas devido ao seu viés centralista não prosperou. O impasse somente foi contornado com a assinatura do Pacto de San José em 1831 (também conhecido como Pacto Federal) que criou a Confederação das Províncias Unidas do Rio da Prata. Contudo, sua existência perdurou mais do que o desejado em razão das disputas políticas internas. Segundo José Carlos Chiaramonte:

En el artículo I del Pacto, las provincias signatarias expresan su voluntad de paz, amistad y unión, 'reconociendo recíprocamente su libertad e independencia, representación y derechos'. Por otra parte, el Pacto abría la posibilidad de un mayor avance en el terreno de la unificación al prever la reunión de un 'Congreso General Federativo' que debería consultar '... la seguridad y engrandecimiento general de la República, su crédito interior y exterior, y la soberanía, libertad e independencia de cada una de las provincias. $^{36}$

O período confederativo (1831 - 1853) foi marcado por altos níveis de descentralização e pela ausência de um governo de âmbito nacional forte.

${ }^{35}$ CHIARAMONTE, José Carlos. El Federalismo Argentino en la Primera Mitad del Siglo XIX. In: Marcello Carmagnani (Coord.). Federalismos Latinoamericanos:

México, Brasil, Argentina. Ciudad de Mexico: Fondo de Cultura Económica, 1993, pp. 81-134.

${ }^{36}$ CHIARAMONTE, José Carlos. El Federalismo Argentino en la Primera Mitad del Siglo XIX. In: Marcello Carmagnani (Coord.). Federalismos Latinoamericanos:

México, Brasil, Argentina. Ciudad de Mexico: Fondo de Cultura Económica, 1993. 
A junção desses dois elementos com o notório desenvolvimento político, administrativo, econômico e geográfico (controlava a saída e entrada de produtos com o comércio internacional) de Buenos Aires, reforçou sua pujança frente às demais unidades. Além disso, sua força política a tornou porta-voz da Confederação no cenário externo.

Rosas emerged as the dominant political figure of the Argentine confederation, eclipsing the provincial federalist caudillos that cofounded the union and crushing sectionalist rebellions within the federation's borders. The government of Buenos Aires assumed control over national military affairs and external relation, and it dominated the union through military force, control of international and interprovincial trade, and the discretionary use of subsidies to resource-starved provincial allies.

O afã de voltar a ser o centro político sob uma forma unitária lançou Buenos Aires a um projeto de reconquista do antigo Vice-reinado que havia se fragmentado durante a independência. A Guerra do Prata, em 1851, trouxe profunda instabilidade política no Cone Sul com as tentativas de anexação do Paraguai e Uruguai. A derrota de Buenos Aires propiciou o Acuerdo de San Nicolás de maio de 1852 que convocou a constituinte. $\mathrm{O}$ texto político de 1853 foi o primeiro documento que conseguiu efetivar um governo de âmbito nacional na Argentina. A adoção da forma federal atendeu aos pleitos das Províncias do interior que se sagraram vitoriosas na disputa interna contra Buenos Aires.

Juan Bautista Alberdi $^{37}$ foi $\mathrm{o}$ mentor intelectual por trás da

37 Sua obra “Las Bases y Puntos de Partida para la Organización Política de la República Argentina" pode ser vista no mesmo grau de importância que a compilação de "O Federalista" teve para os Estados Unidos. O texto de Alberdi, critica de forma enfática, a ausência de governo nacional nas Províncias Unidas (dotadas de baixa densidade demográfica) e afirma ser imperioso aprofundar o povoamento por meio de incentivos à imigração europeia. A unificação tardia permitiu que o estado argentino observasse os acertos e falhas das constituições das antigas unidades que constituíam o Império Hispânico. Defende a ligação física entre as Províncias por meio da expansão de ferrovias, pois a unidade política somente floresceria quando houvesse infraestrutura suficiente para incentivar a circulação de bens e pessoas. No tocante à forma de estado, sustenta que cabe à Assembleia Constituinte determiná-la mediante análise do passado histórico da região que aponta tanto para um viés unitário quanto federalista. Logo, o modelo ideal deve dialogar com esses dois marcos, pois as formas "puras" unitárias e federativas manteriam o impasse e impediriam a unificação territorial. ALBERDI, Juan Bautista. Bases y puntos de partida para la Organización Política de la República Argentina. Buenos Aires: La Cultura Argentina, 1915. 
Constituição de 1853. O renomado intelectual propôs um texto político que dialogava com aspectos federalistas e centralistas, pois acreditava que somente uma federação mais centralizada poderia propiciar o pleno desenvolvimento do Estado argentino. $\mathrm{O}$ Estado que surge a partir do período de independência não pode renegar seu passado político sob pena de fracassar. Por este motivo, era preciso honrar as tradições centralizadoras do Vice-Reinado sem deixar de prestigiar o viés descentralizador também existente ${ }^{38}$. A adoção de um federalismo "radical" (amplamente descentralizado) não teria condições de ser implementado na região, sendo este o principal entrave político para excessiva postergação da formação da nação argentina.

Cabe ressaltar que o ingresso da Província de Buenos Aires à República Argentina somente ocorreu em 1859, pois esta unidade não ratificou a Constituição de 1853. Havia forte resistência da província em ceder poder para o Governo Nacional que emergia, pois não havia interesse político em ser uma unidade coadjuvante quando se supunha ser a protagonista. Nesse sentido:

(...) la razón por que Buenos Aires no quiso ser capital del gobierno unitario de Rivadavia, ni quiere hoy ser capital del gobierno de ningún gobierno común, en cambio del papel que ha hecho durante el desorden, a saber: de metrópoli republicana de trece Provincias, que vivían sin gobierno proprio.

O ingresso ${ }^{39}$ de Buenos Aires em 1860 foi condicionado a mudanças

${ }^{38}$ A proposta teve amplo aceite das Províncias do Interior (ainda que dotado de caraterísticas centralizadoras) porque o modelo proposto retirava poder de Buenos Aires e trazia maior equilíbrio e estabilidade à região. Nesse sentido: "The provinces of the interior wanted a strong central government and sided with Juan Bautista Alberdi's proposal that, in case of sedition, the federal government could intervene in the provinces without their request in order to reestablish order. The province of Buenos Aires instead preferred a federal government with limited powers and sided with Domingo Faustino Sarmiento's proposal to prohibit the federal government from intervening without the explicit request of the local authorities". GIBSON, Edward; FALLETI, Tulia. Unity by the Stick: Regional conflict and the origins of Argentine Federalism. In: Edward Gibson (ed.). Federalism and Democracy in Latin America. Baltimore, MD: The Johns Hopkins Press, 2004, p. 226-254.

${ }^{39} \mathrm{O}$ ingresso da Província era questão de tempo conforme Justo Jose Urquiza previu em seu discurso em 1852: “(...) amo al pueblo de Buenos Aires, me duelo de la ausencia de sus representantes en este recinto. Pero su ausencia no quiere significar un apartamiento para siempre: es un accidente transitorio. La geografía, la historia, los 
na Constituição de $1853^{40}$. A história argentina é repleta de instabilidades que persistirão até o último quartel do século XX.

Em relação ao federalismo fiscal é possível encontrar similaridades com a experiência mexicana. A repartição tributária pensada pelo constituinte de 1853 foi mantida após a reforma de 1860, mas com o passar dos anos foi sendo deturpada pelo governo federal na tentativa de obter mais receitas para fazer jus às necessidades econômicas e demandas sociais. O sistema tributário argentino tinha como premissa a separação de fontes: 1) taxativos (importação, exportação e de selos) pertencentes à União; 2) diretos, de competência estadual, podendo ser utilizados pela Federação em casos excepcionais e de modo temporário e, 3) indiretos, residualmente entregues às Províncias.

No entanto, em 1890, o governo federal instituiu imposto indireto sobre o consumo, que a princípio seria de competência privativa dos Estados. Justificou-se que a Constituição não tinha comando autorizando, mas tampouco proibindo. Além disso, o texto político impunha competências concorrentes para a promoção do desenvolvimento do Estado argentino, sendo, portanto, natural que as faculdades tributárias assim também o fossem para permitir que a União tivesse receita suficiente para cumprir seu papel constitucional. A nova forma de interpretar o texto gerou a bitributação ao qual a separação das fontes buscou evitar. Segundo Pablo María Garat:

En la primera época de la organización constitucional y hasta fines del siglo XIX, el gobierno federal respetó la cláusula del artículo $4^{\circ}$ de la Constitución Nacional, sin recurrir a las "contribuciones" (impuestos) para atender sus necesidades fiscales. Así, entre 1853 y 1891, hay un primer período de clara separación de fuente que se modifica cuando, por la crisis económica de 1890/91, el gobierno federal establece impuestos internos en todo el territorio nacional. Se manifiesta, a partir de allí, un predominio del sistema de concurrencia de fuentes "de hecho" hasta la crisis mundial del 29/30 que lleva al gobierno federal a apropiarse de fuentes invocando el 67 , inciso $2^{\circ}$ de la Constitución

pactos, vinculan a Buenos Aires al resto de la nación. Ni ella puede vivir sin sus hermanos ni sus hermanos sin ella. En la bandera argentina hay espacio para más de catorce estrellas; pero no puede eclipsarse una sola". FRONDIZI, Silvio. El Federalismo en la República Argentina. In: Pedro Pablo Camargo, et. al. (Coords.). Los Sistemas

Federales del Continente Americano. Ciudad de Mexico: Fondo de Cultura Económica, 1972, p. 11-116.

${ }^{40}$ As exigências de Buenos Aires objetivavam limitar o poder do Governo Nacional sobre sua jurisdição e vida política, buscando-se descentralizar o texto para resguardar sua autoridade dentro de sua circunscrição. 
Nacional, asumiendo no sólo la facultad de las provincias en materia de impuesto directos, sino también competencias, funciones y la prestación de servicios que correspondían a aquéllas, consolidándose un proceso creciente de centralización. ${ }^{41}$

Desde o final do século XIX o Governo Central se apropriou das contribuições indiretas com o referendo da Suprema Corte. Com o acirramento das crises econômicas, principalmente a Grande Depressão, a União passou a utilizar também os impostos diretos ainda que ausente o caráter excepcional e transitório. Sobre o tema, a Corte Argentina afirmou que dentro do conceito de transitoriedade há a noção de "tempo necessário para pôr fim a causa que deu origem a instituição do imposto". Tal postura gerou uma mutação do federalismo fiscal argentino, transformando a separação de fontes em uma competência tributária concorrente. Tal como ocorreu no México, a consequência foi a bitributação, que somente foi superada com advento do Sistema de Coparticipação engendrado pelo Governo federal.

(...) a partir de 1935, se sancionó unilateralmente por el Congreso de la Nación el primer régimen de coparticipación impositiva a través de la ley 12.139, con vigencia desde el $1^{0}$ de enero de 1935 que concreta la unificación de los impuestos internos y se proponía como una "ley convenio", ya que preveía la adhesión de las provincias. Es decir que la coparticipación no se adoptó por primera vez como mecanismo de coordinación impositiva ni como instrumento para la distribución o redistribución de tributos propios de las provincias y del gobierno federal, sino como un mecanismo de asignación y compensación por la detracción de recursos tributarios que el gobierno federal efectuaba en detrimento de las provincias, aun cuando ello hubiese sido convalidado por la doctrina de la Corte Suprema de Justicia de la Nación.

Há bastante crítica doutrinária em relação ao sistema criado, sendo a mais ferrenha acerca de sua inconstitucionalidade. Para superar esse ponto, somente em 1994 foi feita uma reforma ao texto de 1853 para a constitucionalização do Sistema de Coparticipação ${ }^{42}$. A lógica criada pelas “Leyes-convenio" impõe que os Estados concordem em não exercer seu poder político tributário em prol da União, cabendo-lhes, como

${ }^{41}$ GARAT, Pablo María. El Sistema de Coparticipación Federal en la Organización Constitucional Argentina. Revista Latinoamericana de Derecho, No. 9-10, 2009.

${ }^{42}$ GARAT, Pablo María. El Sistema de Coparticipación Federal en la Organización Constitucional Argentina. Revista Latinoamericana de Derecho, No. 9-10, 2009. 
compensação, o recebimento de percentuais do montante arrecadado. A tática é muito semelhante à centralização sofrida no México, gerando, inclusive, os mesmos efeitos: enfraquecimento financeiro dos entes e dependência econômica da União ${ }^{43}$. A reforma de 1994 ampliou a redação original do artigo 75, inciso 2 ao estabelecer que as contribuições diretas e indiretas cabem a todos os entes de forma concorrente. Alberto Ricardo Dalla Via é um ferrenho crítico à constitucionalização deste sistema:

No debemos olvidar al respecto que la coparticipación federal es una de las instituciones que más han contribuido a acentuar la dependencia de las provincias al poder central, al lado de ella podrían incluirse a la intervención federal y las declaraciones de estado de sitio. Existen muchos trabajos y estudios que se refieren a esa cuestión más verificable en nuestra realidad e historia reciente. La coparticipación federal nació como una patología ante la insuficiencia de nuestro sistema fiscal de atribución de competencias. Dadas como estaban las circunstancias, no existía ninguna necesidad de incluir el sistema de coparticipación en la Constitución y sí en cambio, hubiera sido conveniente abrir el debate sobre la atribución de fuentes impositivas originarias entre nación y provincias. ${ }^{44}$

Por sua vez, Antonio María Hernández oferece um contraponto interessante sobre o tema:

La reforma, al constitucionalizar la coparticipación bajo estrictas condiciones, también cumplió su objetivo de fortalecer el federalismo. Primeramente, la reforma definió con claridad la distribución de competencias entre el gobierno federal y provincias (...) Dicha ley-convenio debe cumplir además las siguientes condiciones según la ley suprema: 1) El Senado es la Cámara de origen. 2) La sanción debe ser con la mayoría absoluta dela totalidad de los miembros de cada Cámara. 3) No puede ser modificada unilateralmente. 4) tampoco puede ser reglamentada. 5) Debe ser aprobada por las provincias. 6) La distribución entre la nación, las provincias y la ciudad de Buenos Aires, y entre éstas, se efectuará en relación directa a las competencias, servicios y

${ }^{43}$ O quadro fiscal argentino piorou quando em 1989, por iniciativa do governo federal, competências foram devolvidas aos Estados-membros sem o aporte financeiro para implementar os novos encargos. Ou seja, descentralizou-se o déficit e concentrou-se o lucro. O sufocamento das debilitadas finanças estaduais foi inevitável.

${ }^{44}$ VÍA, Alberto Ricardo Dalla. Actualidad del Federalismo Argentino. In: José María Serna de la Garza (Coord.). Federalismo y Regionalismo: Memoria del VII Congreso Iberoamericano de Derecho Constitucional. Ciudad de Mexico: Universidad Nacional Autónoma de Mexico, 2002, p. 39-104.

2 JOURNAL OF INSTITUTIONAL STUDIES 2 (2016) 
funciones de cada una de ellas, contemplando criterios objetivos de reparto. (...) La incorporación del instituto de la ley-convenio a la Constitución es, para nosotros, una transcendental reforma destinada a afianzar el federalismo de concertación, en uno de los capítulos más conflictivos de la historia argentina: la relación financiera entre nación y provincias. ${ }^{45}$

Por mais criticável que o Sistema de Coparticipação seja, é importante reconhecer as vantagens de sua constitucionalização. Se houve interesse político em manter o sistema (vigente desde os anos trinta) é preferível que esteja previsto na Constituição do que em normas infraconstitucionais como ocorre no México ${ }^{46}$. O novo status do Sistema de Coparticipação permite o questionamento na Suprema Corte, por exemplo. Além disso, deu maior rigidez ao exigir atuação política coordenada entre Presidente, Governadores e Parlamentares. Merece destaque a previsão constitucional que proíbe a descentralização de competências sem que seja feito redistribuição fiscal a fim de que as novas responsabilidades tenham fonte para custeio. Contudo, segundo Antonio María Hernández, a despeito da previsão constitucional “(...) el gobierno federal (...) centralizó recursos y federalizó los déficits" ${ }^{47}$. De acordo com

${ }^{45}$ HERNÁNDEZ, Antonio María. La Descentralización del Poder en el Estado Argentino. In: José María Serna de la Garza (Coord.). Federalismo y Regionalismo:

Memoria del VII Congreso Iberoamericano de Derecho Constitucional. Ciudad de Mexico: Universidad Nacional Autónoma de Mexico, 2002.

${ }^{46}$ Destaca-se a observação feita por Alberto Zarza Mensaque: "La norma es compleja y de difícil implementación, tal como lo expresa Pérez Hualde y requiere la sanción de la mencionada ley convenio, que por imperio de la cláusula transitoria sexta de la reforma constitucional debía dictarse antes de finalizar 1996. A la fecha han transcurrido más de seis años, sin haberse logrado el acuerdo necesario entre el Estado federal y las provincias, por lo que el país se sigue manejando con acuerdos sucesivos entre el Estado federal y las provincias, sin la posibilidad de concretar legislativamente los preceptos constitucionales. Estos acuerdos transitorios se modifican frecuentemente en razón que el gobierno federal en situación de insolvencia, no remite automáticamente los fondos recaudados a las provincias y éstas a su vez no concretan la reorganización de sus finanzas". ZARZA MENSAQUE, Alberto. La Crisis Argentina y la Reforma Política Institucional. In: Antonio María Hernández; Diego Valadés (Coords.). Estudios sobre Federalismo, Justicia, Democracia y Derechos Humanos: homenaje a Pedro J. Frías. Ciudad de Mexico: Universidad Nacional Autónoma de Mexico, 2003.

${ }^{47}$ HERNÁNDEZ, Antonio María. La Descentralización del Poder en el Estado Argentino. In: José María Serna de la Garza (Coord.). Federalismo y Regionalismo: 
Leticia Patrucchi, o federalismo fiscal argentino está muito aquém do necessário.

El escenario subnacional en la Argentina ha sido históricamente asimétrico. De modo ilustrativo, y sintético, mientras que cuatro provincias generan el $75 \%$ del Producto Bruto, ocupan $20 \%$ de la superficie y el $63 \%$ de la población (...); catorce concentran $30 \%$ de población, $45 \%$ de superficie y aportan $18 \%$ al Producto Bruto. Asimismo, la capacidad fiscal de las provincias ha sido - a lo largo de las últimas décadas- débil. Sólo un reducido grupo de seis provincias alcanzan hoy a financiar más del $50 \%$ de sus gastos con recursos propios. Como consecuencia la mayor parte de ellas dependen de los recursos que tanto vía coparticipación como a través de otros sistemas de transferencias reciben del gobierno nacional. ${ }^{48}$

Além disso, a referida autora também alerta para um grave problema do sistema de coordenação. A lei 23.548 que detalha a copartipação é 1988 e, apesar do seu caráter transitório continua vigente. Se inicialmente a lei previa uma divisão do montante arrecadado de modo mais favorável às Províncias, com o passar do tempo passou a criar tributos não coparticipáveis, agravando o cenário fiscal.

Mientras que la Ley 23548 estableció el porcentaje de distribución primaria históricamente más alto recibido por las provincias (54,66\% para estas y $42,44 \%$ para la Nación); los acuerdos firmados a lo largo de la década del noventa sumado a la creación de nuevos tributos de carácter no-coparticipable fueron modificando este equilibrio favoreciendo la concentración de recursos en el nivel nacional. (...)Así, a lo largo de la década del noventa y principios de la actual, las provincias sufrieron una reducción significativa -cercana al 30\%- de los recursos que deberían habérsele asignado según lo establecido por la Ley № 23.548. Los principales destinos de estas reducciones han sido el sistema de seguridad social y el mismo gobierno nacional con el fin de financiar sus desequilibrios fiscales. Si consideramos la importancia que estos recursos tienen para la mayoría de las administraciones subnacionales, como

Memoria del VII Congreso Iberoamericano de Derecho Constitucional. Ciudad de Mexico: Universidad Nacional Autónoma de Mexico, 2002, p. 211-274.

${ }^{48}$ PATRUCCHI, Leticia. Federalismo y Coparticipación. Transformaciones PolíticoAdministrativas y Concentración de Recursos Fiscales en la Argentina (1990-2007). Disponível em:

$<$ http://webiigg.sociales.uba.ar/sepure/Publicaciones/Patrucchi\%20(2007)\%20Federalis mo\%20y\%20coparticipacion.pdf $>$. Acesso em: 31 de janeiro de 2017. 
fue presentado anteriormente, estas reducciones vuelven más crítico el predominante desequilibrio fiscal vertical -- asimetría entre los recursos fiscales y las responsabilidades de gasto-- en la Argentina. Asimismo, los años posteriores a la devaluación y las políticas adoptadas en materia tributaria intensificaron esta tendencia. El aumento creciente de la recaudación impositiva a nivel nacional, lo que en parte ha contribuido (desde el lado de los ingresos) al sostenido superávit fiscal de los últimos cuatro años (revirtiendo los resultados deficitarios de la década pasada) se sostiene principalmente por tributos que no tienen carácter coparticipable. ${ }^{49}$

O fato de a Constituição não detalhar as espécies tributárias combinado com ausência de racionalização em um código, torna o sistema fiscal confuso, favorecendo, consequentemente, a União. As leis esparsas que traçam e regulam as transferências fiscais transformam o federalismo fiscal em um verdadeiro labirinto. Além disso, de acordo com Miguel Barrientos, os entes subnacionais possuem considerável aptidão em criar gastos frente sua incapacidade de gerar receitas para custeá-los. Isto é, as transferências constituem, em regra, parte considerável de sua vida financeira. Os governadores têm o benefício político de impor despesas sem ter o ônus de gerar a arrecadação.

Por fim, Ernesto A. O'Connor chama atenção para o grave cenário fiscal. No ano de 2010, a carga tributária argentina equivaleu a 33,48\% do Produto Interno Bruto (PIB), dos quais $28,72 \%$ foram cobrados pela União enquanto os Estados responderam por apenas $4,76 \% .{ }^{50}$ Portanto, assim como ocorre no México, há um forte sufocamento fiscal que fragiliza as unidades subnacionais argentinas, pois ficam dependentes de repasses financeiros da União para efetivar sua administração ${ }^{51}$.

49 PATRUCCHI, Leticia. Federalismo y Coparticipación. Transformaciones PolíticoAdministrativas y Concentración de Recursos Fiscales en la Argentina (1990-2007). Disponível em: $<$ http://webiigg.sociales.uba.ar/sepure/Publicaciones/Patrucchi\%20(2007)\%20Federalis mo\%20y\%20coparticipacion.pdf $>$. Acesso em: 31 de janeiro de 2017.

${ }^{50}$ Cf. JACOBO, Alejandro; O'CONNOR, Ernesto. El Sistema Tributario en el Mundo: Una Comparación con la Argentina. In: Ernesto O'Connor; Jorge Vignale. Sistema Tributario Argentino. Un Análisis Comparativo de la Contribución por Sectores Productivos y de la Equidad Sectorial. (Primera Parte). Buenos Aires: Facultad de Ciencias Económicas de la Universidad Catolica Argentina, 2011, p. 14.

${ }^{51}$ As transferências são mecanismos de fortalecimento das finanças do ente regional, mas têm sido utilizadas como mecanismos de controle e submissão. Nesse sentido: “Con respecto al federalismo fiscal el diseño de un sistema de transferencias 


\section{Modelo Fiscal Brasileiro}

A conquista do território brasileiro se deu em 1500, mas a ocupação por Portugal só teve início, de fato, a partir de 1530. O sistema de Capitanias Hereditárias adotado por D. João III foi uma estratégia de ocupação que retirou do Estado português o ônus de explorar/manter a posse das terras. Assim como na América Hispânica, a colonização do Brasil foi eminentemente exploratória, pois "O que o português vinha buscar era, sem dúvida, a riqueza, mas riqueza que custa ousadia, não riqueza que custa trabalho".

Com a instituição das capitanias, surgiram as primeiras Câmaras Coloniais (poder político) ${ }^{52}$ que associadas com o vasto território e poder dos donatários ${ }^{53}$ trouxeram os primeiros traços descentralizadores. Neste

intergubernamentales debe contemplar para cubrir los inevitables desequilibrios fiscales en los países federales, con un elevado porcentaje de transferencias desde el gobierno central hacia los subnacionales. Estas deben ser preferentemente de carácter automático, condicionado y/o con destino específico, y presupuestario, como ocurre en Australia, Alemania y Canadá, y evitando de este modo las transferencias discrecionales." JACOBO, Alejandro; O'CONNOR, Ernesto. El Sistema Tributario en el Mundo: Una Comparación con la Argentina. In: Ernesto O'Connor; Jorge Vignale.

Sistema Tributario Argentino. Un Análisis Comparativo de la Contribución por Sectores Productivos y de la Equidad Sectorial. (Primera Parte). Buenos Aires: Facultad de Ciencias Económicas de la Universidad Catolica Argentina, 2011, p. 17. Critica-se os grifos acrescentados à fala do ilustre pesquisador argentino. É importante que as transferências intergovernamentais sejam incondicionadas e que permitam a gestão ampla das unidades subnacionais, sob pena de se transformar o ente regional em mera descentralização administrativa, aplicando-se a vontade da União em detrimento da regional.

${ }^{52}$ As Câmaras Municipais poderiam ser criadas por decreto real ou por meio de petição dos moradores locais ao Rei. Eram compostas de "homens bons" eleitos pela elite colonial. Para maiores informações, sugere-se a leitura do artigo "Câmaras Municipais" de Angélica Ricci Camargo. Disponível em:

$<$ http://linux.an.gov.br/mapa/?p=4578>.

${ }_{53}$ Jose Murilo de Carvalho sustenta que a ampla discricionariedade era uma forma de recompensar os gastos financeiros na colonização, pois o donatário tinha poder suficiente para impedir a inspeção da Coroa. Desse modo, afirma que “(...) capitania correspondendo a um feudo, cada donatário a um barão ligado ao rei por um pacto de lealdade e cooperação. Poderíamos também dizer que o sistema se aproximava de uma federação, se da expressão guardamos apenas o aspecto da autonomia política das 
período, havia bastante autonomia local e pouco poder metropolitano:

Não se neguem, todavia, os efeitos descentralizadores, dispersivos das donatarias. Efeitos inevitáveis, decorrentes do isolamento geográfico, da extensão da costa, capazes de gerar núcleos de autoridade social, sem que a administração real permitisse a consolidação da autonomia política. As oligarquias locais, resistentes ao controle central, terão sua base no século XVI, mal toleradas sempre, desde o advento do governo-geral e da progressiva centralização logo instaurada. (...) Olhos vigilantes, desconfiados cuidavam para que o mundo americano não esquecesse o cordão umbilical, que lhe transmitia a força de trabalho e lhe absorvia a riqueza. $\mathrm{O}$ rei estava atento ao seu negócio.

A instituição do sistema de Governo-Geral em 1549 foi um ensaio metropolitano para combater a dispersão interna, mas o localismo persistiu. Com advento da Guerra Napoleônica, a Corte buscou refúgio nas terras brasileiras, centralizando, assim, o poder político e administrativo no Rio de Janeiro. De acordo com Raymundo Faoro, a chegada da Corte gerou profunda projeção interna ao fazer com que as capitanias dispersas e desarticuladas gravitassem em torno da capital.

Com a independência do Brasil em 1822, adotou-se a forma monárquica e unitária. O principal objetivo da centralização política em torno do Rei D. Pedro I foi a manutenção da integridade geográfica ${ }^{54}$. É importante ressaltar que a forma republicana adotada ao longo de toda a extensão hispânica culminou em uma profunda pulverização territorial. Durante as discussões políticas da Constituinte de 1823, José Bonifácio de Andrade e Silva, defensor dos ideais antiescravistas, sugeriu o fim do

unidades componentes do todo". CARVALHO, José Murilo de. Pontos e Bordados: Escritos de História e Política. Belo Horizonte, MG: Editora UFMG, 2005, p. 156.

${ }^{54}$ Raymundo Faoro sustenta com veemência que se não fosse pelo regime monárquico adotado, o Brasil não teria mantido suas dimensões territoriais. "A organização do Estado entrelaça-se, dentro das tendências em conflito e sob o dilaceramento centrífugo das capitanias, ao cuidado superior de manter e soldar a unidade política do país, tarefa gigantesca e incerta diante dos obstáculos geográficos e dos valores provinciais não homogêneos." Também afirma que José Bonifácio foi ferrenho articulador da forma imperial porque para ele “(...) a unidade do Império, objetivo comum, não se alcançaria pela adesão das províncias, num pacto fluidamente confederativo, mas por imperativo de lealdade dinástica". FAORO, Raymundo. Os Donos do Poder: formação do patronato político brasileiro. 11ํㅡㄹ ed. São Paulo, SP: Globo, 1997, p. 279. 
tráfico negreiro, mas mostrou-se contrário a imediata abolição, pois se a Constituição afetasse um dos pilares que sustentavam a formação do Estado brasileiro (as oligarquias tinham imenso plantel de escravos) a unidade estaria abalada e dificilmente o regime imperial conseguiria conter os levantes regionais. A Constituinte, contudo, foi dissolvida por ter esvaziado em excesso os poderes do Imperador, outorgando-se a Carta de 1824. Em resposta, criou-se no Nordeste a Confederação do Equador (Ceará, Rio Grande do Norte, Paraíba e Alagoas) para confrontar a centralização do governo no Rio de Janeiro e o total sufocamento das autonomias locais ${ }^{55}$. Apesar do fracasso do movimento, questões envolvendo a forma unitária persistiram ao longo de todo o período imperial.

As tensões políticas que culminaram na abdicação de D. Pedro I em 1831 foram responsáveis pelo primeiro ensaio formal federativo no Brasil. A Câmara dos Deputados articulou os pleitos provinciais transformandoos em projeto de reforma à Carta de 1824. Pregava, basicamente, a criação de Assembleias Provinciais, Executivos Municipais e divisão de receitas tributárias entre Governo Central e Governos Provinciais ${ }^{56}$. Segundo Aureliano Cândido Tavares Bastos:

${ }^{55}$ As Câmaras foram esvaziadas politicamente com a implementação do Império para sufocar a autonomia e garantir a unidade territorial. A lei de organização municipal de $1^{\circ}$ de outubro de 1828 dissipou qualquer esperança de alteração desse cenário ao impor rígido controle das Câmaras pelos Conselhos Gerais, Presidentes de Províncias e pelo Governo Geral. "As câmaras tinham sido outrora instrumento da aristocracia rural em suas manifestações de rebeldia contra a Coroa, e tiveram papel ativo, embora de eficácia duvidosa, no próprio movimento da independência. Depois que os sucessores daqueles agitados colonos haviam conseguido dominar o poder político central, essa antiga função das câmaras já não seria motivo de benemerência, mas demonstração de grave indisciplina, que cumpria reprimir prontamente". LEAL, Victor Nunes.

Coronelismo, enxada e voto. $6^{\circ}$ ed. São Paulo, SP: Alfa-Ômega, 1993, p. 74.

${ }^{56}$ Nossa tradição de discriminação das fontes tributárias remonta ao período imperial. "No Império, apesar de algumas tentativas parciais anteriores, foi o Ato Adicional que pôs em foco o problema da discriminação, entre as rendas gerais e as provinciais. Seu art. 10, no $\mathrm{V}$, conferia às assembleias provinciais o poder de legislar sobre a fixação das despesas municipais e provinciais, e os impostos para elas necessários, contanto que estes não prejudicassem as 'imposições gerais do Estado'. A primeira lei que realizou a completa repartição das rendas foi a de no 99, de 31 de outubro de 1835, que enumerou as gerais, deixando às províncias o poder tributário remanescente". LEAL, Victor Nunes. Coronelismo, enxada e voto. 6o ed. São Paulo, SP: Alfa-Ômega, 1993. 
Em 1831 (...) a câmara dos deputados votara que o Brasil seria monarquia federativa. Propuseram-se também, posto não o votasse a câmara, duas significativas medidas: uma para que cada província tivesse a sua constituição particular, feita por suas assembleias; outra para que o governo fosse provisoriamente vitalício na pessoa do imperador D. Pedro II, e depois temporário na pessoa de um presidente das províncias confederadas do Brasil. $^{57}$

A reforma não foi totalmente aceita pelo Senado por entender que a descentralização almejada em um período de fragilidade política (período regencial) propiciaria a fragmentação territorial. Portanto, buscando compor interesses, foram feitas concessões por meio do Ato Adicional de 1834, que, se por um lado implementou Assembleias Provinciais, dividiu a receita fiscal e eliminou o Conselho de Estado, por outro manteve o Poder Moderador, a vitaliciedade dos Senadores e não permitiu a criação de Executivos municipais. $O$ ímpeto pela descentralização que sempre esteve presente finalmente obteve ressonância no ordenamento jurídico. $\mathrm{O}$ período político subsequente (regencial) foi assolado por revoltas. Em relação ao tema, José Murilo de Carvalho sustenta:

La experiencia de la Regencia tuvo profundo efecto en la élite política. Los mismos liberales que la habían defendido se asustaron de los resultados. El más típico de ellos, Evaristo da Veiga, ya vislumbraba, en 1835, la anarquía en todo el Imperio. Brasil, según él, corría el riesgo de sumergirse en la inestabilidad de los países de las antiguas colonias españolas y podría desmembrarse. El regente Feijó, otro liberal convencido, pensaba en 1836 que las instituciones del país peligraban, que la provincia de Rio Grande ya había separado y que tal vez Pernambuco también lo haría. Asimismo, la desintegración fue percibida por un visitante francés, el conde de Suzannet, que estuvo en Brasil entre 1842 y 1843. Según este observador, la unidad de Brasil era tan sólo aparente, todas las provincias querían la separación y su sueño era la república al estilo norteamericano. ${ }^{58}$

${ }^{57}$ BASTOS, Aureliano Cândido Tavares. A Província: Estudo sobre a Descentralização no Brazil. Rio de Janeiro, RJ: B.L. Garnier, 1870.

${ }^{58}$ CARVALHO, José Murilo de. Federalismo y Centralización en el Imperio Brasileño: Historia y Argumento. In: Marcello Carmagnani (Coord.). Federalismos

Latinoamericanos: México, Brasil, Argentina. Ciudad de Mexico: Fondo de Cultura Económica, 1993, p. 51-80. 
Em resposta, o governo regencial editou a Lei $\mathrm{n}^{\mathrm{o}} 105$ de 12 de maio de 1840 (Lei Interpretativa) que fulminou o Ato Adicional de 1834. Além disso, antecipou-se a maioridade de D. Pedro II. Portanto, o início do Segundo Reinado teve como marca a centralização política. Com o alcance da estabilidade e fim de movimentos separatistas, os pleitos pela descentralização voltaram a ecoar. A lógica imperial se viu ao avesso, pois se no surgimento do Estado brasileiro o sufocamento das autonomias foi necessário para manutenção territorial, a centralização passou a ser vista como mecanismo que incentivaria o desmembramento diante do clames por maiores níveis de autonomia. Diante da resistência do regime monárquico em ceder poder, implementou-se a República em 15 de novembro de 1889 para adotar a forma federal e atender as demandas regionais.

Atualmente, no aspecto fiscal, o Brasil possui melhor cenário do que os Estados latinos analisados em razão da discriminação de rendas ${ }^{59}$ que esteve presente nas atuais constituições republicanas. A Constituição de 1891 trouxe um federalismo fiscal rigidamente discriminado, pois havia o objetivo de deixar extremamente claro os domínios de tributação dos Estados e União (Município não foi contemplado). No entanto, apesar de constitucionalmente discriminados, os impostos da União (importação, consumo, selo e loterias) eram cumulativamente tributados pelos Estados (exceto o de importação) o que gerava problema de dupla tributação.

Tendo como parâmetro o período imperial, é inegável que o surgimento da federação promoveu o aumento de receitas tributárias próprias principalmente para os estados do cone sul. No entanto, as demais unidades sofreram efeito inverso, pois ficaram fiscalmente dependentes do Governo Central em razão de suas novas obrigações constitucionais.

Como era de se esperar, principalmente pelos federalistas, a proclamação da República contribuiu para a transferência de parte da carga tributária para os recém-nomeados Estados da Federação. Com isso, observa-se uma elevação da receita de alguns Estados, notadamente aqueles relacionados à produção cafeeira, como era o caso de São Paulo.

No tocante à tributação, faz parte da história do Brasil a adoção de

${ }^{59}$ Amílcar de Araújo Falcão define a discriminação como separação em termos expressos, unívocos e inconfundíveis a cada ente federativo de modo que se configure como competências privativas ou exclusivas. O resultado é um sistema rígido de discriminação. Cf. FALCÃO, Amílcar de Araújo. Sistema Tributário Brasileiro: Discriminação de Rendas. Rio de Janeiro, RJ: Edições Financeiras, 1965. 
tributos indiretos ${ }^{60}$. A figura do Imposto de Renda - IR, por exemplo, somente conseguiu ser implementada em 1922, no entanto, em 1891 Rui Barbosa já havia tentado instituir o tributo direto, mas fracassou diante da ausência de apoio político. Neste sentido:

No Brasil, porém, até hoje, a atenção dos governos se tem concentrado quase só na aplicação do imposto indireto, sob a sua manifestação mais trivial, mais fácil e de resultados mais imediatos: os direitos de alfândega. E do imposto sobre a renda, por mais que se tenha falado, por mais que se lhe haja proclamado a conveniência e moralidade, ainda não se curou em tentar a adaptação, que nossas circunstâncias permitem e as nossas necessidades reclamam.

A crise de 1929 influenciou na ruptura institucional (Revolução de 1930), tendo como principal consequência a ascensão de Getúlio Vargas e promulgação da Constituição de $1934^{61}$ de viés mais centralista do que a pretérita ${ }^{62}$. O texto político tentou racionalizar o sistema tributário, contemplou Município com competência tributária própria ${ }^{63}$ e vedou a bitributação. A Carta de 37 pouco alterou no cenário fiscal.

A Constituição de 1946, por seu turno, buscou reforçar o federalismo. Por isso, implementou transferências verticais a fim de enrobustecer as

${ }^{60}$ Acerca deste tema, Fernando José Amed, sustenta que a estrutura tributária da Constituição de 88 merece as críticas, pois "Embora descentralizador, com acentuado perfil federalista, o sistema tributário saído da Constituinte começou a receber críticas e restrições logo no dia seguinte à sua aprovação, por ser considerado extremamente complexo, pouco transparente e injusto, pois apresenta uma carga tributária com uma peso de mais de $2 / 3$ de impostos indiretos e menos de $1 / 3$ de impostos diretos". AMED, Fernando José; NEGREIROS, Plínio José Labriola de Campos. História dos Tributos no Brasil. São Paulo, SP: SINAFRESP, 2000.

${ }^{61}$ Sob a égide da Constituição de 1934, os Estados obtiveram o imposto sobre circulação de mercadorias (antigo Imposto sobre Vendas e Consignações, IVC). 62 Apesar de não ter mexido de forma significativa na autonomia financeira, o texto de 1934 acentuou a centralização das competências legislativas promovidas pela Emenda no 26 à Constituição de 1891. Se nos últimos anos de vigência da primeira constituição brasileira o direito do trabalho passou para o rol de atribuições da União ao lado do direito civil, penal e comercial, a Constituição de 1934 fechou o ciclo ao incluir o processo civil. Em geral o texto de 1934 fortaleceu o Governo Federal assim como ocorreu em outros países federais à época.

${ }^{63}$ Os impostos municipais eram atribuídos pelos Estados nas respectivas leis de organização municipal. 
receitas dos entes subnacionais. Contudo, o sistema tributário brasileiro continuou bastante complexo e confuso. Somente com a Emenda Constitucional $\mathrm{n}^{\mathrm{o}} 18$ de 1965 seria dada efetiva racionalidade com advento do Código Tributário Nacional. Criou-se o Sistema Tributário Nacional, discriminou-se impostos segundo suas bases econômicas, suprimiu-se inúmeros outros tidos como excessivos e alterou-se competências. Em relação a este último ponto, é preciso frisar que houve excessiva concentração na União ainda que acompanhada de ampliação das transferências a título compensatório. Apesar da notória concentração fiscal, os índices não foram tão extremados como no México e Argentina.

As mudanças fiscais implementadas no início da década de 60 geraram a federalização de impostos, mas com transferências governamentais a fim de manter o federalismo fiscal equilibrado ${ }^{64}$.

Na primeira metade da década de 60, a União, os estados e municípios eram responsáveis por cerca de $64 \%$, 31\% e 5\% da arrecadação, respectivamente. Computadas as transferências, cabiam aos três níveis de governo, na mesma ordem, em torno de 60\%, 34\% e 6\% em 1960. Por força da Emenda Constitucional $\mathrm{n}^{\mathrm{o}}$ 5/61, de 21 de novembro de 1961, que reforçou o sistema de transferências intergovernamentais, os últimos percentuais sofreram significativa alteração. Assim, em 1965, em meio à reforma tributária que se processava, a União mantinha em torno de $55 \%$ dos recursos disponíveis para o setor público, cabendo a estados e municípios cerca de $35 \%$ e $10 \%$ deles, respectivamente. A reforma tributária de 1964/67 compunha uma estratégia de desenvolvimento segundo a qual a orientação e o controle do processo de crescimento caberiam ao governo federal, o que exigia a centralização das decisões econômicas. (...) A reforma previa, no entanto, que as unidades subnacionais contassem com recursos suficientes para desempenhas suas funções sem atrapalhar o processo de crescimento, principalmente por meio da arrecadação do ICM e de um sistema de transferências

${ }^{64}$ As transferências ganham importância em federações eminentemente cooperativas, como é o caso da brasileira. Em razão de maior atuação em conjunto, é preciso que se reforce os caixas dos entes subnacionais. Não é recomendável redistribuir obrigações sem fazer o mesmo em relação aos tributos. Nesse sentido: “(...) pode-se constatar que o federalismo brasileiro, originado por intermédio da segregação, organiza-se, predominantemente, sob a forma cooperativa. Além disso, seu formato não se apresenta equilibrado, uma vez que há clara predominância do poder nas mãos do governo central em detrimento dos outros entes subnacionais, motivo pelo qual estes possuem apenas relativa autonomia". 
intergovernamentais, que garantia receita para unidades cuja capacidade tributária fosse precária.

No entanto, o período ditatorial radicalizou a centralização e desarticulou o sistema criado, atingindo alarmantes percentuais de concentração na década de 70. A União chegou a deter cerca de $76 \%$ da carga tributária, além disso, reduziu significativamente os percentuais a título de transferência. O sufocamento fiscal somente começou a ser revertido nos anos 80 em razão dos ares democráticos que se aproximavam.

A partir de 1984, observa-se um forte processo de desconcentração dos recursos. (...) Mas não foi apenas o aumento do montante das transferências que provocou a desconcentração. Ela resultou também da perda do poder de arrecadar da União, fenômeno que não se reproduziu no nível estadual. Assim, a participação da União na arrecadação dos três níveis de governo caiu cerca de cinco pontos percentuais entre 1983 e 1988, enquanto sua participação no total da receita tributária disponível teve uma queda de quase 10 pontos percentuais no mesmo período. (...) Quanto à desconcentração dos recursos disponíveis, a nítida preferência demonstrada pelos governos subnacionais por recursos transferidos vis-à-vis sua obtenção mediante esforço tributário próprio resultou, em face da omissão das autoridades fazendárias federais no processo de concepção do sistema tributário, no excessivo aumento das transferencias.

Como se percebe pela leitura do atual texto constitucional, a excessiva centralização fiscal na União foi combatida. Contudo, o afã descentralizador tributário foi desprovido de racionalidade.

Na constituinte, procuramos dar mais autonomia aos Estados e Municípios com a descentralização tributária, mas sem nenhuma racionalidade; na verdade, foi fruto de pressões políticas. (...) com essa nova repartição, criamos um grande problema para a União, que procura ampliar sua receita com contribuições, onerando o setor produtivo, aumentando a carga fiscal indireta e reduzindo a competitividade da produção nacional perante o mercado internacional. ${ }^{65}$

${ }^{65}$ SERRA, José. AFONSO José Roberto Rodrigues. O Federalismo Fiscal à Brasileira: Algumas Reflexões. Revista do BNDES, V.6, № 12, 3-30, 1999. 
$\mathrm{O}$ excessivo entusiasmo gerou desequilíbrio fiscal ${ }^{66}$. Na tentativa de transferir recursos para os entes subnacionais, o constituinte promoveu a sangria dos principais impostos federais (IR e IPI) ao impor percentuais significativos a título de transferência vertical. $O$ percentual, por exemplo, que era de $12 \%$ (5\% para Fundo Estadual, 5\% para Fundo Municipal e 2\% para Fundo Especial) foi majorado para $47 \%$ (21,5\% para Fundo Estadual, 22,5\% para Fundo Municipal e 3\% para Programa de Financiamento das Regiões Norte, Nordeste e Centro-oeste).

O equilíbrio fiscal é delicado e difícil concretização. Por este motivo, segundo José Maurício Conti, as transferências intergovernamentais incondicionadas (diretas e indiretas) como é o caso dos Fundos e IPVA, são imprescindíveis, pois os entes subnacionais detém competência própria insuficiente para cobrir seus gastos correntes básicos, tornando necessário um aporte financeiro extra que possa ser livremente utilizado a fim de fazer frente às suas obrigações constitucionais. Dificilmente o ente infranacional terá tributos próprios suficientes para arcar com seus gastos em razão do princípio da eficiência alocativa, em que se atribui a competência para tributar ao ente da Federação capaz de fazê-lo com maior eficiência. O possível efeito negativo deste desenho fiscal é o desestímulo de uma gestão responsável pelos entes federados, já que terão o bônus de determinar gastos sem o ônus de gerar receita para cobri-los. Nesse sentido:

O problema do federalismo fiscal no tocante às transferências intergovernamentais reside no fato de que tanto estados quanto municípios ficaram extremamente dependentes do repasse desses valores. Ora, se é verdade que tais transferências constituem elemento importante para a sobrevivência das entidades subnacionais e para a manutenção de sua autonomia, não menos verdade é que algumas esferas governamentais se sentem acomodadas nessa situação, deixando de instituir tributos próprios. Tal prática, na verdade, acaba por reduzir a autonomia desses entes, os quais se habituam a exigir cada vez mais repasse por parte do governo central.

${ }^{66}$ Fernando Luiz Abrucio afirma que a partir da redemocratização os Governadores obtiveram um imenso poder sobre o equilíbrio federativo. O principal indicativo desta força advém das eleições diretas em 1982 para os governos estaduais. Esse afã regional atingiu a constituinte e promoveu a intensa pulverização de receitas tributárias. Esse fenômeno foi possível porque a perda de força política da União e do Presidente da República nos últimos anos da ditadura representaram o aumento do poder político dos Estados-membros e dos Governadores. Cf. ABRUCIO, Fernando Luiz. Os Barões da Federação: Os Governadores e a Redemocratização Brasileira. São Paulo, SP: HUCITEC, 1998. 
Diante de um cenário que esvaziou as finanças federais, a partir dos anos 90, a União passou a majorar e instituir contribuições sociais67 em razão do seu caráter não compartilhável. ${ }^{68}$ Sob a Constituição de 88 , Estados $^{69}$ e Municípios arrecadam até $33 \%$ do bolo tributário que chega a

${ }^{67}$ Para José Augusto Moreira de Carvalho, "Se é verdade que a descentralização ocorreu nesse sentido, o mesmo não se pode afirmar em relação às atribuições destinadas à União, motivo pelo qual lhe foi retirada parcela de receita, mas não seus encargos. A nova situação obrigou a União a obter recursos de outra maneira. Lançou mão, então, das contribuições, tributos em que o produto da arrecadação não precisa ser repartido aos demais entes federados. (...) em razão da natureza das contribuições sociais, o produto de sua arrecadação é vinculado, devendo ser direcionado a despesas atinentes à seguridade social, por exemplo. Como forma de atenuar tais vinculações, foram criados o Fundo Social de Emergência (FSE), o Fundo de Estabilização Fiscal (FEF) e, atualmente, a Desvinculação de Recursos da União (DRU), esta responsável por livrar $20 \%$ da arrecadação da União no tocante a impostos, contribuições sociais e de intervenção no domínio econômico, de forma a proporcionar que referidos recursos sejam destinados a outras despesas que não as estabelecidas originariamente pela Constituição. O problema é que esse procedimento acaba gerando um círculo vicioso, cujo resultado é praticamente a anulação da descentralização surgida com a Carta de 1988". CARVALHO, José Augusto Moreira de. Federalismo e Descentralização: Características do Federalismo Fiscal Brasileiro e seus Problemas. In: José Mauricio Conti; Fernando Facury Scaff; Carlos Eduardo Faraco Braga (Coords.). Federalismo Fiscal: Questões Contemporâneas. Florianópolis, SC: Conceito, 2010, p. 55-82. ${ }_{68}$ Para Fernando José Amed, a União buscou reequilibrar suas receitas com tributos ruins como as contribuições que são eminentemente cumulativas que penalizam a produção e o consumidor nacional: "Esse modelo de sistema tributário, no qual, têm um grande peso os impostos cumulativos, vigente a partir de 1989, provocou um significativo aumento da carga tributária no país que, no curto tempo de quatro anos, quando esse tipo de tributação ganhou relevância, passou de 25,09\% para 30,18\% do PIB (...) O apelo para os tributos cumulativos, que incidem em cascata, foi justificado pelo governo da União sob a alegação de que, com a partilha de receitas estabelecida pela Carta de 88, houve excessiva descentralização dos recursos sem a correspondente transferência de encargos para Estados e Municípios". AMED, Fernando José; NEGREIROS, Plínio José Labriola de Campos. História dos Tributos no Brasil. São Paulo, SP: SINAFRESP, 2000.

${ }^{69}$ A carga tributária nacional concentra-se em poucos tributos. O ICMS, por exemplo, compõe quase $1 / 4$ do montante total, que somado ao IR, Cofins, IPI e Contribuição sobre a Previdência são responsáveis por quase 70\% de toda arrecadação. O Brasil é o único país no mundo no qual o maior tributo arrecadado fica a cargo das unidades 
$43 \%$ quando se incluem as transferências constitucionais. ${ }^{70}$ Dados mais recentes elaborados pela Fundação Getúlio Vargas indicam que a receita dos Municípios tem aumentando significativamente desde 1988 (União teve seu percentual reduzido de $60,1 \%$ para $56,9 \%$; Estado de $26,6 \%$ para $24,6 \%$, mas o Município aumentou de $13,3 \%$ para $18,5 \% 71$ ). Mas o que se percebe, na verdade, conforme atesta Fernando Rezende, é que a constituinte de 1986 confundiu autonomia financeira com liberdade para gastar sem a equivalente responsabilidade de tributar, aumentando-se exageradamente, para atingir este objetivo, as transferências intergovernamentais. Em regra, a receita da grande maioria dos entes subnacionais cresceu em função do incremento destas transferências. Esse cenário, por si só, rompe com o fim precípuo desta técnica fiscal: perda de seu caráter compensatório para assunção de papel de principal fonte de recursos orçamentários dos Municípios e Estados.

\section{CONCLUSÃO}

As expressões federativas são únicas e têm íntima relação com as práticas políticas do passado. A história colonial da América Latina teve profunda influência na descentralização de corte mais acanhado quando comparado com outras federações do mundo. No entanto, isto não é motivo para negar ou rechaçar os modelos mexicano, argentino e brasileiro. Apesar de reconhecer a individualidade de cada modelo, é inegável que há bastante similaridades.

Em relação ao aspecto fiscal, é preciso lembrar que este é o grande pilar de sustentação da forma federativa, pois sem Poder Político Tributário não há que se falar nos desdobramentos da autonomia. Neste aspecto, há um cenário temeroso. México e Argentina sofreram alterações informais em seus textos ao longo do século XIX e XX no tocante a autonomia financeira dos entes políticos. O federalismo fiscal que deveria

subnacionais, gerando problemas como sonegação e guerras fiscais, cenário nocivo às finanças públicas. VARSANO, Ricardo, et. al. Uma Análise da Carga Tributária do Brasil. Rio de Janeiro, RJ: IPEA, 1998, p. 8. Um dos principais motivos da existência da guerra fiscal é a dificuldade de se estabelecer patamares aceitáveis em relação ao ICMS.

${ }^{70}$ SERRA, José. AFONSO José Roberto Rodrigues. O Federalismo Fiscal à Brasileira: Algumas Reflexões. Revista do BNDES, V.6, № 12, 3-30, 1999, p. 8.

${ }^{71}$ PATU, Gustavo. Em 24 anos, fatia de municípios na arrecadação sobre de 13,3\% para 18,5\%. Folha de São Paulo, 02 dez. 2014. Disponível em:

$<$ http://dinheiropublico.blogfolha.uol.com.br/2014/12/02/em-24-anos-fatia-demunicipios-na-arrecadacao-sobe-de-133-para-185/>. Acesso em: 31 de janeiro de 2017. 
ser pautado em discriminação de fontes e, por isso, mais rígido, foi flexibilizado ao se incutir um corte concorrente. A anarquia fiscal e o sufocamento da economia foi a principal consequência da desregulação feita ao arrepio do texto constitucional. Buscando superar este cenário, ambos países optaram por centralizar tributos na União a fim de racionalizar o sistema "de cima para baixo". O grande efeito colateral foi o aniquilamento do poder político tributário dos entes infranacionais. Dentro da esfera deste elemento da autonomia, também está a faculdade do ente poder usar suas competências tributárias a fim de estimular sua economia por meio de isenções ou reduções de alíquotas, por exemplo. Algo que lhes é vedado quando cedem este poder ao Governo Central. Além disso, há um indesejável cenário em que os entes têm melhores condições para criar rubricas de despesa do que meios para gerar receitas. Ao deixar de exercer ou exercer de forma eminentemente restrita suas capacidades fiscais, a tendência é que não haja gestão fiscal em âmbito local, pois as unidades infranacionais apenas possuem expectativa do quanto irão receber, sem ter noção do volume real para fins de eventual contingenciamento. Em um estado federal não é desejável a existência de entes reféns do poder econômico da União sob pena de se corromper o fim precípuo do federalismo: pluralidade de centros decisórios que dialogam e até rivalizam entre si em determinados momentos.

$\mathrm{O}$ caso brasileiro repete o cenário exposto ainda que em menor dimensão. A Constituição de 1988 tentou revolucionar o federalismo, mas o fez de modo não muito adequado. Primeiro porque optou por tributos indiretos como fonte principal, segundo porque confundiu autonomia financeira com aptidão de indicar gastos. A sangria cometida em razão das transferências intergovernamentais reforçou o caixa dos entes infranacionais de modo inadequado. As transferências não servem para substituir a autonomia financeira, mas sim para reforçar suas receitas. Além disso, ao se tornarem a principal fonte financeira para inúmeros entes, perdeu-se seu principal aspecto, isto é, mecanismo de transferência com cunho redistributivo a fim de propiciar o pleno desenvolvimento das regiões. Em vez de tornar os entes menos dependentes da União, o desenho fiscal de 88 gerou o efeito contrário.

\section{REFERÊNCIAS}

ABRUCIO, Fernando Luiz. Os Barões da Federação: Os Governadores e a Redemocratização Brasileira. São Paulo, SP: HUCITEC, 1998. 
ACHA, Luis Manuel Pérez de. Federalismo Hacendario (Propuestas Constitucional y Legal 2007). In: Gabriela Ríos Granados (Coord.). Reforma Hacendaria en la Agenda de la Reforma del Estado. Ciudad de Mexico: Universidad Nacional Autónoma de Mexico, 2009.

ALBERDI, Juan Bautista. Bases y puntos de partida para la Organización Política de la República Argentina. Buenos Aires: La Cultura Argentina, 1915.

AMED, Fernando José; NEGREIROS, Plínio José Labriola de Campos. História dos Tributos no Brasil. São Paulo, SP: SINAFRESP, 2000.

BARROSO, Luís Roberto. Direito Constitucional Brasileiro: o Problema da Federação. Rio de Janeiro, RJ: Forense, 1982.

BASTOS, Aureliano Cândido Tavares. A Província: Estudo sobre a Descentralização no Brazil. Rio de Janeiro, RJ: B.L. Garnier, 1870.

CAMACHO, César. Propuesta de un Nuevo Diseño Competencial para el Federalismo Mexicano. In: José María Serna de la Garza (Coord.). Federalismo y Regionalismo: Memoria del VII Congreso Iberoamericano de Derecho Constitucional. Ciudad de Mexico: Universidad Nacional Autónoma de Mexico, 2002.

CARMAGNANI, Marcello (Coord.). Federalismos Latinoamericanos: México, Brasil, Argentina. Ciudad de Mexico: Fondo de Cultura Económica, 1993.

CARPIZO, Jorge. Sistema Federal Mexicano. In: Pedro Pablo Camargo, et. al. (Coords.). Los Sistemas Federales del Continente Americano. Ciudad de Mexico: Fondo de Cultura Económica, 1972. 
CARVALHO, José Augusto Moreira de. Federalismo e Descentralização: Características do Federalismo Fiscal Brasileiro e seus Problemas. In: José Mauricio Conti; Fernando Facury Scaff; Carlos Eduardo Faraco Braga (Coords.). Federalismo Fiscal: Questões Contemporâneas. Florianópolis, SC: Conceito, 2010.

CARVALHO, José Murilo de. Federalismo y Centralización en el Imperio Brasileño: Historia y Argumento. In: Marcello Carmagnani (Coord.). Federalismos Latinoamericanos: México, Brasil, Argentina. Ciudad de Mexico: Fondo de Cultura Económica, 1993.

CARVALHO, José Murilo de. Pontos e Bordados: Escritos de História e Política. Belo Horizonte, MG: Editora UFMG, 2005.

CHIARAMONTE, José Carlos. El Federalismo Argentino en la Primera Mitad del Siglo XIX. In: Marcello Carmagnani (Coord.). Federalismos Latinoamericanos: México, Brasil, Argentina. Ciudad de Mexico: Fondo de Cultura Económica, 1993.

CONTI, José Maurício. Considerações sobre o Federalismo Fiscal Brasileiro em uma Perspectiva Comparada. In: José Mauricio Conti; Fernando Facury Scaff; Carlos Eduardo Faraco Braga (Coords.). Federalismo Fiscal: Questões Contemporâneas. Florianópolis, SC: Conceito, 2010.

DALLARI, Dalmo de Abreu. O Estado Federal. São Paulo, SP: Ática, 1986.

DONGHI, Tulio Halperín. Historia Contemporanea de America Latina. Madrid: Alianza Editorial, 2005.

FALCÃO, Amílcar de Araújo. Sistema Tributário Brasileiro:

Discriminação de Rendas. Rio de Janeiro, RJ: Edições Financeiras, 1965. 
FAORO, Raymundo. Os Donos do Poder: formação do patronato político brasileiro. 11ª ed. São Paulo, SP: Globo, 1997.

GARAT, Pablo María. El Sistema de Coparticipación Federal en la Organización Constitucional Argentina. Revista Latinoamericana de Derecho, No. 9-10, 2009.

GIBSON, Edward; FALLETI, Tulia. Unity by the Stick: Regional conflict and the origins of Argentine Federalism. In: Edward Gibson (ed.). Federalism and Democracy in Latin America. Baltimore, MD: The Johns Hopkins Press, 2004.

HERNÁNDEZ, Antonio María. La Descentralización del Poder en el Estado Argentino. In: José María Serna de la Garza (Coord.). Federalismo y Regionalismo: Memoria del VII Congreso Iberoamericano de Derecho Constitucional. Ciudad de Mexico: Universidad Nacional Autónoma de Mexico, 2002.

JACOBO, Alejandro; O'CONNOR, Ernesto. El Sistema Tributario en el Mundo: Una Comparación con la Argentina. In: Ernesto O'Connor; Jorge Vignale. Sistema Tributario Argentino. Un Análisis Comparativo de la Contribución por Sectores Productivos y de la Equidad Sectorial. (Primera Parte). Buenos Aires: Facultad de Ciencias Económicas de la Universidad Catolica Argentina, 2011.

LEAL, Victor Nunes. Coronelismo, enxada e voto. $6^{\circ}$ ed. São Paulo, SP: Alfa-Ômega, 1993.

MERINO, Mauricio. El Federalismo e Los Dineros. Nexos: Sociedad, Periodismo y Literatura, No. 210, 1995. Disponível em:

$<$ http://www.nexos.com.mx/?p=7442>. Acesso em: 21 de janeiro de 2016. 
MIRANDA CAMARENA, Adrián Joaquín. Análisis del Federalismo Hacendario Mexicano. 2010. 268 f. Tese (Doutorado em Direito Constitucional), Universidad Carlos III de Madrid, Madrid, 2010.

PATRUCCHI, Leticia. Federalismo y Coparticipación.

Transformaciones Político-Administrativas y Concentración de Recursos Fiscales en la Argentina (1990-2007). Disponível em: $<$ http://webiigg.sociales.uba.ar/sepure/Publicaciones/Patrucchi\%20(2007 $\% 20$ Federalismo $\% 20 \mathrm{y} \% 20$ coparticipacion.pdf $>$. Acesso em: $31 \mathrm{de}$ janeiro de 2017.

PATU, Gustavo. Em 24 anos, fatia de municípios na arrecadação sobre de 13,3\% para 18,5\%. Folha de São Paulo, 02 dez. 2014. Disponível em: $<$ http://dinheiropublico.blogfolha.uol.com.br/2014/12/02/em-24-anosfatia-de-municipios-na-arrecadacao-sobe-de-133-para-185/>. Acesso em: 31 de janeiro de 2017.

RUIZ, Javier Obregón. Fortalecimiento del Federalismo Fiscal en México. Documento de Trabajo (Fundación Rafael Preciado Hernández A.C.), No. 482, 2013. Disponível em: $<$ https://www.academia.edu/9435848/DOCUMENTOS DE TRABAJO F ortalecimiento del Federalismo Fiscal en M\%C3\%A9xico 482>. Acesso em: 31 de janeiro de 2017.

SERNA DE LA GARZA, José María. Aspectos Constitucionales del Federalismo Fiscal Mexicano. In: Gabriela Ríos Granados (Coord.). Reforma Hacendaria en la Agenda de la Reforma del Estado. Ciudad de Mexico: Universidad Nacional Autónoma de Mexico, 2009.

VARSANO, Ricardo, et. al. Uma Análise da Carga Tributária do Brasil. Rio de Janeiro, RJ: IPEA, 1998.

VÍA, Alberto Ricardo Dalla. Actualidad del Federalismo Argentino. In: José María Serna de la Garza (Coord.). Federalismo y Regionalismo: 
Memoria del VII Congreso Iberoamericano de Derecho

Constitucional. Ciudad de Mexico: Universidad Nacional Autónoma de Mexico, 2002.

WATTS, Ronald. Comparing Federal Systems in the 1990s, Kingston, Ont: Queen's University, 1996.

ZARZA MENSAQUE, Alberto. La Crisis Argentina y la Reforma Política Institucional. In: Antonio María Hernández; Diego Valadés (Coords.). Estudios sobre Federalismo, Justicia, Democracia y Derechos Humanos: homenaje a Pedro J. Frías. Ciudad de Mexico: Universidad Nacional Autónoma de Mexico, 2003

ZIMMERMANN, Augusto. Teoria Geral do Federalismo Democrático. Rio de Janeiro, RJ: Lumen Juris, 1999.

Federalismo Fiscal na América Latina: os casos de México, Argentina e Brasil Tax Federalism in Latin America: the cases of Mexico, Argentina and Brazil Submetido em: 2017-11-20 